\title{
ACCREDITING \\ AND THE \\ SHERMAN ACT
}

\section{Clark C. Havighurst* and Peter M. Brody**}

\section{INTRODUCTION}

When members of an industry collaborate in formulating quality standards for industry products or services, or in certifying products, credentialing individuals, or accrediting institutions that meet such standards, questions of antitrust law inevitably arise. To the extent that such actions are carried out by organizations sponsored by competitors in one or more of the industries affected, they involve concerted action that must withstand scrutiny under section 1 of the Sherman Act. ${ }^{1}$ Despite a significant volume of relevant case law, however, antitrust doctrine applicable to competitor-sponsored accrediting ${ }^{2}$ remains murky. Indeed, there is no consensus on whether standard setting and accrediting, without more, harm competition at all, thus qualifying for possible characterization as a restraint of trade. ${ }^{3}$ In addition, there is no agreement on either the antitrust rationale or the standard of review under which a court might evaluate a standard that an accrediting body imposes on an industry or an action that it takes in an individual case. ${ }^{4}$ Finally, courts and analysts have looked for harm to competition only in markets in which accreditation affects the behavior or opportunities of individual firms; there has been no comparable appreciation of the importance of also fostering competitive conditions in the

Copyright $\odot 1995$ by Law and Contemporary Problems

* William Neal Reynolds Professor of Law, Duke University.

** Partner, Ropes \& Gray, Washington, D.C.

1. 15 U.S.C. \& 1 (1988 \& Supp. IV 1992) (prohibiting "every contract, combination ... , or conspiracy, in restraint of trade or commerce"). For discussion of the concerted-action issue in accrediting cases, see Daniel v. American Bd. of Emergency Medicine, 802 F. Supp. 912, 924-25 (W.D.N.Y. 1992) (medical specialty board sued for raising its threshold requirements for certification in the specialty as a way of limiting competition in the field; authorities cited for holding that a professional association is a combination of its members for purposes of the Sherman Act if the members have independent commercial interests in achieving the allegedly anticompetitive object of the conspiracy). See also 7 PHILIP AREEDA, ANTITRUST LAW I 1477, at 343 (1986) (trade and standard-setting associations treated as continuing combinations of their members). But see infra note 143.

2. In this article, accrediting and other derivatives of the verb accredit refer to all efforts by private entities to establish industrial, educational, or professional quality standards of general application and to all related certifying activities. In practice, the term certification is generally used where the quality of industrial products or the competence of skilled personnel is being verified; accreditation usually applies to institutions providing educational, health, and other services or to discrete programs within such institutions. The antitrust issues are virtually the same whatever type of "accrediting" is involved.

3. See infra text accompanying notes $76-98$.

4. See infra text accompanying notes 99-115. 
separate markets for information and opinion in which accrediting bodies themselves compete, producing and offering possibly biased or self-serving information and advice for public consumption.

This article seeks to demonstrate and correct some doctrinal and analytical shortcomings in antitrust law as it applies to private accrediting. A crucial objective is to assist courts in minimizing the anticompetitive features of accreditation and in maximizing its procompetitive benefits-including efficient standardization of products and services and the provision of information and advice useful to consumers and other market participants. Another goal is to make. it easier to predict the outcome of antitrust challenges to accrediting standards or decisions. As things now stand, litigation over accrediting practices tends to be unfocused and protracted because of the lack of clear legal principles to guide factual analysis and to facilitate the granting of summary judgment in appropriate cases. This uncertainty places severe burdens on the litigants-both challengers and accrediting bodies-and makes litigation a significant business risk and cost for accrediting organizations.

II

\section{Is Private ACCRediting AdeQuately Policed under ANTITRust LAW?}

The adoption and application of quality standards by industry groups can, and in most instances does, enhance competition and promote efficiency by clarifying and informing choices that market actors must make. But private accrediting may sometimes enable special interests in an industry to limit the independence of individual competitors or to deny desirable options to consumers. This potential for abuse of private power and preemption of competitor freedom and consumer choice poses a challenge for antitrust enforcers and courts. Without discouraging private accreditors from performing the procompetitive function of overcoming chronic information deficits in private markets, ${ }^{6}$ antitrust law must prevent self-appointed private groups from exercising unauthorized, quasi-governmental regulatory power over particular sectors of the economy. Although most private accrediting is performed in apparent good faith, good faith alone does not guarantee that a particular

5. The insight that antitrust law might usefully concentrate on protecting competition and pluralism in accrediting-that is, in the production of information and advice concerning goods and services available in the marketplace-was first advanced in Clark C. Havighurst \& Nancy M. King, Private Credentialing of Health Care Personnel: An Antitrust Perspective (pts. 1 \& 2), 9 AM. J.L. \& MED. 131, 263, 295-330 (1983), and is developed in Part IV, infra.

6. For a discussion of the beneficial functions that private accrediting performs in real-world markets facing significant information problems and of the significance of its potential for abuse (all addressed in the closely analogous context of conferring private credentials on technical personnel), see Havighurst \& King, supra note 5, at 132-38, 150-57. See also Clark C. Havighurst, Applying Antitrust Law to Collaboration in the Production of Information: The Case of Medical Technology Assessment, 51 LAW \& CONTEMP. PROBS. 341, 343-56 (Spring 1988) (discussing accrediting in the market for information concerning medical technologies). 
accrediting program is compatible with dynamic competition, as the Sherman Act requires it to be. The discussion here suggests some reasons to doubt that antitrust law, as interpreted and applied today, effectively ensures that private accrediting has predominantly procompetitive effects in every case. Later discussion argues that the remedy for this problem lies not in stricter judicial scrutiny of accrediting actions but in a different direction altogether.

\section{A. Whose Interests Does Antitrust Law Protect?}

Disappointed applicants for accreditation are by far the most common plaintiffs in antitrust suits against accreditors. Thus, a typical lawsuit is the one recently brought by the Massachusetts School of Law against the American Bar Association (the "ABA") and alleged co-conspirators for not granting the school the accreditation it claims to need to compete effectively with other law schools; ${ }^{7}$ the plaintiff in that case contends that its innovative, low-cost program serves students well despite offending a number of accreditation standards maintained by the ABA in collaboration with the legal education establishment. The great majority of antitrust-accreditation cases are similar: private suits brought by a competitor seeking some seal of approval vital or helpful to its competitive success. ${ }^{8}$ Even if the results in these cases satisfied the complaints of such plaintiffs, however, there would remain a question whether competition itself and the interest of consumers in maintaining competition were adequately protected. If a plaintiff is interested only in enjoying the same status as its competitors, it may seek or settle for a remedy that achieves that objective but fails to restore competitive conditions.?

Occasionally antitrust actions have been brought against accreditors by would-be suppliers of goods or services to firms affected by accrediting standards. The goal of such litigants has been to prevent an accrediting program or standard from foreclosing a market for their wares. Cases of this kind have been brought by chiropractors, for example, against the American Medical Association (the "AMA") for causing the dominant accreditor of hospitals to adopt standards under which hospitals refused to deal with chiropractors. ${ }^{10}$ Antitrust cases initiated by suppliers to accredited firms reveal the possibility that competitors in one field, by controlling accrediting in another

7. See Massachusetts Sch. of Law at Andover, Inc. v. ABA, 846 F. Supp. 374 (E.D. Pa. 1994). All individual defendants were eventually dismissed on jurisdictional grounds. 853 F. Supp. 843 (E.D. Pa. 1994).

8. The leading Supreme Court cases on accrediting are all of this kind. Allied Tube \& Conduit Corp. v. Indian Head, Inc., 486 U.S. 492 (1988); American Soc'y of Mechanical Eng'rs, Inc. v. Hydrolevel Corp., 456 U.S. 556 (1982); Radiant Burners, Inc. v. Peoples Gas Light \& Coke Co., 364 U.S. 656 (1961).

9. See generally Havighurst \& King, supra note 5, at $328-30$ (discussing remedy issues and observing that private plaintiffs in these cases may find "[f]orcing their way into the exclusive club ... more advantageous to them than ... restoring competition").

10. Wilk v. AMA, 895 F.2d 352 (7th Cir. 1990); Chiropractic Coop. Ass'n of Mich. v. AMA, 1986-2 Trade Cas. (CCH) I 67,294 (E.D. Mich. 1986). 
field, may unduly limit outlets available to their competitors. ${ }^{11}$ Once again, however, granting relief to such plaintiffs, while possibly advancing some consumer interests, may not fully restore competition.

Customers, as well as suppliers, of firms subjected to restrictive accrediting standards might also be expected on occasion to invoke antitrust law against accreditors in order to prevent foreclosure of certain purchasing options. Thus, a chain of drugstores might contest a current plan by the American Council on Pharmaceutical Education (the "ACPE") to discontinue accrediting five-year training programs for pharmacists and to accredit only six-year (Pharm.D.) programs. ${ }^{12}$ Such a plaintiff would seem to have standing, as a consumer of the output of pharmacy schools, to bring an antitrust suit alleging both a potential diminution of competition in the market for pharmacy training and a conspiracy to raise entry costs, curtail supply, and raise wages in the market for pharmacists. ${ }^{13}$ (One might also imagine a class action against the ACPE by students of pharmacy - who are even more obviously consumers of pharmacy education. Claiming antitrust injury from the reduced freedom of schools to design their own educational programs, the students might hope to recover in treble damages the costs of the added year of training that the new standard would force them to incur before qualifying for employment as pharmacists. ${ }^{14}$ ) Purchasers in markets where the effects of accreditation are directly felt should attract particular sympathy as antitrust plaintiffs. Unlike a competitor-plaintiff,

11. Other cases brought by supplier-plaintiffs include Medical CME Assocs. v. Accreditation Council for Continuing Medical Educ., 1990-2 Trade Cas. 1 69,245 (N.D. Ill. 1990) (supplier of packaged CME programs, claiming conspiracy "to exclude entities outside the control of the medical profession from competition in the CME market," sued CME accreditor for threatening to disaccredit medical school because of its association with the supplier); Levin v. Joint Comm'n on Accreditation of Hosps., 354 F.2d 515 (D.C. Cir. 1965) (podiatrist challenged physician-dominated hospital accreditor's rule requiring supervision of podiatrists by a physician).

12. See ACPE, PROCEDURES AND SCHEDULE FOR THE REVISION OF ACCREDITATION STANDARDS AND Guidelines (9th Ed. 1990). But see ABT Associates INC., Evaluation of THE PROPOSED 6. YeAR Pharm.D. MANDATE (report prepared for American Stores Co., Nov. 24, 1993) [hereinafter EVALUATION] (on file with author) (critiquing the ACPE proposal).

13. For the requirement that a plaintiff, to have standing to bring a private antitrust suit, must have suffered "antitrust injury," not just some disadvantage from a violation of the antitrust laws, see Brunswick Corp. v. Pueblo Bowl-O-Mat, Inc., 429 U.S. 477 (1977). For a case suggesting, incredibly, that a party denied accreditation by an allegedly unlawful accrediting monopolist has not suffered antitrust injury, see Staudinger v. Educational Comm'n for Foreign Med. Graduates, 1994 WL 410875 (S.D.N.Y. 1994).

The ACPE might claim immunity under the Noerr-Pennington doctrine (see infra notes 46,47 and accompanying text) in a suit for an injunction requiring it to continue accrediting five-year programs. Although that doctrine might block suits for money damages resulting solely from independent action by government (see infra note 14), it should not bar injunctive relief to prevent the promulgation of a standard tainted by the unlawful acts of one or more competitors.

14. There would be a problem, however, in recovering damages for injuries suffered as a result of actions taken by state licensing authorities in reliance upon the ACPE's new accrediting requirement. In Allied Tube, for example, "no damages were imposed for the incorporation of [the accreditor's standards] by any government." Allied Tube \& Conduit Corp. v. Indian Head, Inc., 486 U.S. 492, 500 (1988); see also Sessions Tank Liners, Inc. v. Joor Mfg., Inc., 17 F.3d 295 (9th Cir.) (following Allied Tube, court held defendant firm immune from damages for injuries attributable solely to state action induced by its misrepresentations to standard-setting organization), cert. denied, $115 \mathrm{~S}$. Ct. 66 (1994). Injunctive relief would not necessarily be barred, however. See supra note 13. 
whose complaint may be only a private grievance against being denied a favorable status or against being labeled an inferior competitor, a purchaserplaintiff would be invoking antitrust law for its customary purpose of protecting consumer welfare and "competition, not competitors."15

Yet even though the goal of the antitrust laws is to maintain competition primarily for the benefit of consumers, very few antitrust cases against accreditors have been brought by customers of firms whose output is standardized or otherwise regulated through private accrediting. ${ }^{16}$ For this reason and because competitors affected by accrediting actions may not themselves be adequately policing private accreditors, some practices that are unduly restrictive of consumer choice may escape detection and sanction under the antitrust laws. To be sure, public antitrust enforcement agencies are charged with looking out for consumer interests. But they have rarely challenged run-of-the-mill standard setting or accrediting programs. Instead, public enforcement actions have generally focused on standard setting that occurs in conjunction with price fixing ${ }^{17}$ or with some other clear restraint, such as a true boycott of unaccredited products or suppliers. ${ }^{18}$ The Federal Trade Commission (the "FTC"), however, does exercise some informal oversight of standard setting and

15. Brunswick Corp., 429 U.S. at 488 ("antitrust laws ... were enacted for 'the protection of competition, not competitors"”) (quoting Brown Shoe Co. v. United States, 370 U.S. 294, 320 (1962)); Reiter v. Sonotone Corp., 442 U.S. 330, 343 (1979) (legislative history said to "suggest that Congress designed the Sherman Act as a "consumer welfare prescription'") (quoting ROBERT BORK, THE ANTITRUST PARADOX 66 (1978)). Although the goals of antitrust law have been widely debated, modern thinking focuses principally on promoting efficiency and competition for the benefit of consumers and is less concerned about preserving or protecting competitors as such. See generally ERNest Gellhorn \& William E. Kovacic, ANTITRUST LAW AND ECONOMICS in a NUTSHELl 3136 (1994).

16. Indeed, only two such cases have been found, both involving consumers of education. In Zavaletta v. ABA, 721 F. Supp. 96 (E.D. Va. 1989), third-year law students sued because their law school had not been accredited. In dismissing the complaint on other grounds, the court assumed that the students, "as consumers of legal education," had standing to bring the suit. Id. at 98; see also Welch v. American Psychoanalytic Ass'n, 1986-1 Trade Cas. 67,037 (S.D.N.Y. 1986) (clinical psychologists attacked, among other things, a standard requiring accredited residency training programs in psychoanalysis to accept only medical school graduates).

It should be noted here that, conceptually, the competitor-plaintiffs in most antitrust suits over accreditation, although not customers of the industry being accredited, can be viewed as consumers of accrediting services. Indeed, although their hardships flow from their position as competitors in the accredited field, their complaints are essentially about the nature and quality of the information and advice produced by the sole or dominant accreditor in the field. Thus, the real desire of these plaintiffs is to be evaluated under different standards, which they contend would serve the ultimate consumer, as well as themselves, better. This observation points up the importance of maintaining competitive conditions, to the extent possible, in the market for accrediting itself, as explored in Part IV infra.

17. See, e.g., National Macaroni Mfr. Ass'n v. FTC, 345 F.2d 421, 426 (7th Cir. 1965) (standardizing product "with the design and result of depressing the price of an essential raw material" held to constitute a form of price fixing); Milk \& Ice Cream Can Inst. v. FTC, 152 F.2d 478 (7th Cir. 1946) (condemning standardization facilitating charging of uniform prices).

18. See, e.g., Fashion Originators' Guild of Am., Inc. v. FTC, 312 U.S. 457 (1941) (industry group not only declared clothes to be copies of original designs but organized unlawful boycotts to preclude their production and sale). 
accrediting programs and may, in that way, prevent some abuses. ${ }^{19}$ It should, for example, be able to prevent the promulgation of some standards having no technical merit and to discourage in some cases the manipulation of standards to harm individual competitors.

Nevertheless, neither private nor public antitrust enforcement seems capable of rooting out self-interest in the making and application of accrediting standards. As later discussion will show, there are simply too many issues on which the judgment of an industry group, though open to question, cannot finally be impugned. For example, an antitrust agency or court would be hardpressed to question the ABA's opinion concerning the maximum number of classroom hours that a law school may require its professors to teach ${ }^{20}$ or the ACPE's view that entry-level pharmacists should have at least six years of formal education. ${ }^{21}$ Thus, not only do antitrust courts have few opportunities to vindicate consumer interests directly, but they lack principles with which to do so reliably in close cases. It is far from clear that antitrust law, as currently administered, is capable of protecting consumers against private accrediting that unduly limits their market options.

\section{B. Deference to Professionalism in Antitrust Law}

The application of antitrust law to accrediting activities has reflected not only judicial acceptance of the judgment of industry insiders on close technical questions but also occasional deference to accreditors who claim to be speaking for a recognized profession and to be upholding its values. At one time, the socalled learned professions were widely thought-though they were never authoritatively held-to be engaged in something other than "trade or commerce" and thus to fall altogether outside the reach of the Sherman Act. ${ }^{22}$ Likewise, certain activities of professional organizations were widely deemed to

19. To a greater extent than the Antitrust Division of the Department of Justice, the FTC has long been interested in industrial standards, receiving and reviewing complaints from aggrieved interests, issuing advisory opinions, and commenting publicly on issues related thereto. See, e.g., Second Opinion Letter, 78 F.T.C. 1628 (1965) (advisory opinion setting forth guidelines for standards and certification); FTC, Bureau OF CONSUMER PROTECTION, STANDARDS AND CERTIFICATION (1983) (final staff report) (extensive survey and critique of practices) [hereinafter STANDARDS AND CERTIFICATION]. Although the FTC staff has taken the view that all standard setting restrains trade (see infra note 87 and accompanying text), that position is debatable.

20. The ABA also requires that faculty salaries not be below a minimum amount. Although antitrust enforcers see them as a red flag, such standards are easily distinguishable from horizontal price fixing. Moreover, as standards, they are rationally related to the objective of ensuring the quality of teaching.

21. Again, the merits of the standard, though debatable (see infra notes $40 \& 41$ ), are not a proper question for judicial resolution.

22. The main reason why federal antitrust law was not generally applied to the professions until the $1970 \mathrm{~s}$, however, was the inability of federal law to reach localized conduct not affecting interstate commerce. See generally Clark C. Havighurst, A Comment: The Antitrust Challenge to Professionalism, 41 MD. L. REV. 30, 31-34 (1981). For the latest Supreme Court ruling extending the jurisdictional reach of the antitrust laws over professional activity, see Summit Health, Ltd. v. Pinhas, 500 U.S. 322 (1991) (physician allowed to challenge hospital action affecting his staff privileges if challenged restraint could potentially affect interstate commerce). 
have noncommercial purposes and thus to be inappropriate objects of antitrust scrutiny. ${ }^{23}$

To be sure, the Supreme Court rejected blanket immunity of these kinds in the Goldfarb case in 1975, holding that "the nature of an occupation, standing alone, does not provide sanctuary from the Sherman Act."24 Despite the demise of the putative learned-professions exemption in Goldfarb, however, the idea has persisted that, because rendering professional services differs from ordinary commerce, professionals should sometimes be judged by softer antitrust rules than ordinary businesses. The Supreme Court encouraged such arguments by dicta in a Goldfarb footnote ${ }^{25}$ and continued in later decisions to leave open the possibility that the professional status of antitrust defendants might make a difference in some future case. Nevertheless, each of the Court's successive statements of that possibility over time has narrowed the ground for possible exceptions to standard antitrust principles. ${ }^{26}$ Moreover, the Court has yet to decide an antitrust case in favor of professionals by applying a more generous substantive rule to their anticompetitive actions. Indeed, it has had no difficulty in finding violations in several cases where professional defendants claimed that their. worthy purposes should serve as a defense for a restrictive practice. ${ }^{27}$

23. See, e.g., Marjorie Webster Jr. College, Inc. v. Middle States Ass'n of Colleges and Secondary Sch., Inc., 432 F.2d 650, 654 (D.C. Cir.) (early antitrust challenge by a disappointed applicant for accreditation rejected on ground that antitrust laws were not intended to apply to "the non-commercial aspects of the liberal arts and the learned professions"), cert. denied, 400 U.S. 965 (1970).

24. Goldfarb v. Virginia State Bar, 421 U.S. 773, 787 (1975) (applying Sherman Act to minimum fee schedule maintained by state bar association). Although some post-Goldfarb cases continued to treat such activities as education and professional credentialing as virtually exempt from antitrust scrutiny, see e.g., Nara v. American Dental Ass'n, 526 F. Supp. 452 (W.D. Mich. 1981); Selman v. Harvard Medical Sch., 494 F. Supp. 603 (S.D.N.Y. 1980), later cases have made slear that any notion of an outright exemption for accreditation activities was swept away with the rest of the learnedprofession exemption. See, e.g., Welch v. American Psychoanalytic Ass'n, 1986-1 Trade Cas. (CCH) I 67,037 (S.D.N.Y. 1986); United States Dental Inst. v. American Ass'n of Orthodontists, 396 F. Supp. 585 (N.D. Ill. 1975). The idea that accrediting may continue to enjoy some protection from antitrust scrutiny as a presumptively "noncommercial" activity remains alive, however, resuscitated by recent respectful treatment by a court of appeals of the antitrust holding in the Marjorie Webster case. United States v. Brown Univ., 5 F.3d 658, 667-68 (3d Cir. 1993); see infra notes 30-33 and accompanying text.

25. Goldfarb, 421 U.S. at $788 \mathrm{n} .17$, in which the Court stated, inter alia, "The public service aspect, and other features of the professions, may require that a particular practice, which could be viewed as a violation of the Sherman Act in another context, be treated differently."

26. See United States v. Oregon State Medical Soc'y, 343 U.S. 326, 336 (1952) ("forms of competition usual in the business world may be demoralizing to the ethical standards of a profession"); Goldfarb, 421 U.S. at 788 n.17; National Soc'y of Professional Eng'rs v. United States, 435 U.S. 679, 696 (1978) (interpreting Goldfarb footnote as meaning only that "the nature of the competition in [professional] services may vary" and opining that "ethical norms may serve to regulate and promote this competition, and thus fall within the Rule of Reason"); Arizona v. Maricopa County Medical Soc'y, 457 U.S. 332, 348 (1982) ("Nor does the fact that doctors-rather than nonprofessionals-are the parties to the price-fixing agreements support the respondents' position."); FTC v. Indiana Fed'n of Dentists, 476 U.S. 447, 462 (1986) (rejecting as "flawed both legally and factually" "noncompetitive "quality of care' justifications for [the challenged concerted action]"); Patrick v. Burget, 486 U.S. 94, 105 (1988) (rejecting, as an inappropriate "challenge to the wisdom of applying the antitrust laws to the sphere of medical care," an immunity claim based on the contention that "effective [professional] peer review is essential to the provision of quality medical care").

27. See supra note 26, especially the Professional Engineers, Indiana Federation, and Patrick cases. In Professional Engineers, 435 U.S. at 695, the Court refused even to listen to evidence supporting the 
Although the Court has expressed a reluctance to declare practices of professional groups unlawful per $\mathbf{s e}^{28}$ it has also balked in recent years at finding conduct illegal per se in cases involving nonprofessionals, indicating that it is not the professional status of defendants so much as the complexity of the situations encountered that calls for closer analysis under the rule of reason. ${ }^{29}$ A close reading of Supreme Court precedents reveals no basis for relaxing antitrust standards specifically for professional activities.

Nevertheless, both the Supreme Court and lower courts have usually been careful to appear respectful of professionals' claims and motives in antitrust cases. $^{30}$ Thus, courts have often paid lip service to professionalism even as they have condemned specific practices. Also, lower courts have often nodded toward professionalism in upholding practices that would probably have been upheld in any event. ${ }^{31}$ Although what courts do might seem more important than what they say, such dicta and surplusage may easily be taken as signs that deference to professionals qua professionals may sometimes be appropriate. To be sure, there are few recent antitrust cases in which professional defendants have clearly been given special dispensation to restrain trade. ${ }^{32}$ It is still

petitioners' claim that their anticompetitive agreement protected consumers against unsafe engineering work, declaring that such a claim constituted "nothing less than a frontal assault on the basic policy of the Sherman Act."

28. FTC v. Indiana Fed'n of Dentists, 476 U.S. at $458-59$ ("[W]e have been slow to condemn rules adopted by professional associations as unreasonable per se."); see also United States v. Brown Univ., 5 F.3d 658 (3d Cir. 1993) (refusing to treat agreement among universities to limit amount of financial aid to individual students as per se violation and even to apply "quick look" principle, even though agreement could be characterized as price fixing). The significance of per se rules is explained infra in notes 69-70 and accompanying text. Accrediting in particular has been spared treatment as a per se violation. E.g., In re Appraiser Foundation Antitrust Litigation, 1994 WL 637705 at *5-*7 (D. Minn. 1994); Medical CME Assocs. v. Accreditation Council for Continuing Medical Educ., 1990-2 Trade Cas. (CCH) 69,245 (N.D. Ill. 1990); Paralegal Inst., Inc. v. ABA, 475 F. Supp. 1123, 1128-29 (E.D.N.Y. 1979).

29. FTC v. Indiana Fed'n of Dentists, 476 U.S. at 447, 458-59 (1986) ("[W]e have been slow ..., in general, to extend per se analysis to restraints imposed in the context of business relationships where the economic impact of certain practices is not immediately obvious.") (citing Broadcast Music, Inc. v. CBS, Inc., 441 U.S. 1 (1979)). Although the Supreme Court purported to apply a per se rule to professional organizations in one case, its actual analysis in that case was a model of rule-of-reason analysis. Arizona v. Maricopa County Medical Soc'y, 457 U.S. 332, 351 (1982) (maximum fee schedule set by county medical group held unlawful as price fixing, but only after Court determined that "the limited record in this case is not inconsistent with the presumption that the respondents' agreements will not significantly enhance competition"). This perplexing and internally inconsistent opinion by Justice Stevens is matched by another one in which he declared that per se analysis was inappropriate in analyzing agreements by the nation's colleges to allocate the market for televising football games, but then proceeded to show only that the restraint was naked and lacked any procompetitive virtue and therefore warranted prohibition without regard to market power-that is, per se treatment. NCAA v. Board of Regents, 468 U.S. 85 (1984). These cases and other modern developments demonstrate that the old dichotomy between "per se" and "rule of reason" cases is no longer of much help in analyzing any but run-of-the-mill conspiracies.

30. See, e.g., cases cited supra note 26.

31. See, e.g., Kreuzer v. American Academy of Periodontology, 735 F.2d 1479, 1496 (D.C. Cir. 1984) (in leaving only limited room for plaintiff to challenge credentialing requirement, court "reiterate[d] its strong support for professional associations dedicated to furthering the public good").

32. But see Wilk v. AMA, 719 F.2d 207 (7th Cir. 1983) (holding that an organized boycott by physicians of chiropractors might be defensible on basis of a sincere concern for "scientific method" and 
unsettling, however, to encounter regular suggestions that professionals have more freedom to interfere with competition than less elite competitors. Although antitrust counselors probably do not advise their professional clients that they need not obey the law like everyone else, kind judicial words for professionalism can still be cited to divert judicial attention from possible abuses by professional organizations, particularly in such seemingly noncommercial activities as accrediting. ${ }^{33}$ In general, one cannot be confident that antitrust courts are sufficiently vigilant against the possibility that accrediting bodies may exercise excessive authority over the forms that competition may take in professional fields.

\section{Government Deference to Private Accreditors}

The principal reason why some private accreditors may wield undue quasiregulatory power is not, however, any shortcoming in private or public antitrust enforcement against accrediting bodies or in antitrust doctrine applicable to professional elites. It is, instead, the decision by government in numerous situations expressly to accept accreditation by a private entity as a basis for granting or withholding some public recognition or public benefit. The federal government has, for example, long recognized the Joint Commission on Accreditation of Healthcare Organizations (the "JCAHO") as the principal judge of which hospitals are good enough to participate in the Medicare and Medicaid programs; ${ }^{34}$ although hospitals are technically free to qualify by other

for the welfare of patients), cert. denied, 467 U.S. 1210 (1984).

33. The Wilk holding, probably did not survive the Supreme Court's decision in Indiana Federation of Dentists. See supra note 26. Case law continues to suggest, however, that when a professional association adopts a restraint "premised on public service or ethical norms," Arizona v. Maricopa County Medical Soc'y, 457 U.S. 332, 349 (1982), it may be harder for an antitrust plaintiff to establish the requisite harm to competition and consumer welfare. See, e.g., United States v. Brown Univ., 5 F.3d 658, 672 (3d Cir. 1993):

[W] hile professional organizations aim to enhance the profits of their members, they and the professionals they represent may have greater incentives to pursue ethical, charitable, or other non-economic objectives that conflict with the goal of pure profit maximization. While it is well settled that good motives themselves "will not validate an otherwise anticompetitive practice," courts often look at a party's intent to help [them] judge the likely effects of challenged conduct.

(quoting NCAA v. Board of Regents, 468 U.S. 85, 101 n.23 (1984)). Despite the language quoted here from $N C A A$, the Court in that case also suggested in dictum that a nationwide collective agreement by institutions of higher learning to refuse to pay wages to "student-athletes" could be defended as being in aid of "the maintenance of a revered tradition of amateurism in college sports." Id. at 120; see also supra note 26 . It is clear that some courts remain uncomfortable about letting the antitrust laws be invoked with full force against anticompetitive conduct by educational and professional organizations.

34. See, e.g., Timothy Stoltzfus Jost, The Joint Commission on Accreditation of Hospitals: Private Regulation of Health Care and the Public Interest, 24 B.C. L. REV. 835 (1983). Although the situation with respect to hospitals remains largely unchanged today, see Timothy Stoltzfus Jost, Medicare and the Joint Commission on Accreditation of Healthcare Organizations: A Healthy Relationship?, 57 LAW \& CONTEMP. PROBS. 15 (Autumn 1994), the Health Care Financing Administration has recently published regulations declaring its willingness to accept accreditation by entities other than the dominant physician-sponsored ones as presumptively valid evidence of the acceptability of various institutional providers of health care. 58 Fed. Reg. 61,816 (1993). See generally Eleanor D. Kinney, Private Accreditation As a Substitute for Direct Government Regulation in Public Health Insurance Programs: 
means, the physician-dominated JCAHO has long had an effective monopoly over hospital accreditation. ${ }^{35}$ Similarly, in the field of education, the Department of Education (the "DOE") has long granted professional groups virtually exclusive franchises to accredit educational institutions and programs of different kinds; although originating to enable the government to avoid giving student aid or other support to substandard institutions, DOE recognition has given many educational accrediting bodies more credibility and de facto authority than they would otherwise enjoy. ${ }^{36}$ Federal law thus supports the idea that, in some fields, private organizations can be trusted to set and administer industry-wide standards that would normally be the province of public policy.

State and local governments also delegate substantial policymaking poivers to private groups. For example, building codes and similar regulations often accord definitive weight to privately conferred seals of approval, thus opening the door for private interests to exploit accrediting for exclusionary purposes. ${ }^{37}$ Legislative and regulatory deference to private groups is especially widespread in the regulation of the professions and other licensed occupations. As noted by the plaintiff in the Massachusetts School of Law case, for example, forty-two states refuse bar admission to graduates of American law schools not accredited

When Is It Appropriate?, 57 LAW \& CONTEMP. PROBS. 47 (Autumn 1994). See also infra note 137.

35. Hospitals have therefore had to operate with special regard for the needs and interests of physicians. See supra notes 10, 11 and accompanying text; see also Clark C. Havighurst, Doctors and Hospitals: An Antitrust Perspective on Traditional Relationships, 1984 DUKE L.J. 1071, 1084-92 (arguing that "the medical profession, working largely through the JCAH in recent years, has effectively dictated the essential terms upon which hospitals may deal with physicians").

36. See 20 U.S.C.A $\S \S 1058,1061,1141,1145$ (1990 \& West Supp. 1994) (DOE recognition of accreditors whose accreditation is necessary for an educational institution to be eligible for certain federal funds); 34 C.F.R. $\$ 602$ (1993). See generally Matthew W. Finkin, The Unfolding Tendency in the Federal Relationship to Private Accreditation in Higher Education, 57 LAW \& CONTEMP. PROBS. 89 (Autumn 1994). Public reliance on private accreditors in the field of education is often said to reflect the reluctance of government, which is in any event inhibited by the First Amendment, to become directly involved in regulating private education. The idea that more than one accreditor might assist the government in identifying quality programs has only begun to surface in DOE thinking. See 53 Fed. Reg. 25,096 (1988) (departmental comment, in adopting new regulations, rejecting suggestions that DOE, to avoid public confusion, should expressly discourage competition among accreditors):

With regard to the use of the regulations to limit proliferation and fragmentation in accreditation, the Secretary determined that arbitrarily limiting the number of accrediting bodies serves no educational purpose. The Secretary wishes to foster appropriate competition among accrediting bodies and does not wish to see the recognition process used in such a way as to create a monopoly in any educational field.

37. One danger is that individual firms will subvert or abuse a neutral accreditor's processes to harm a competitor. See, e.g., Allied Tube \& Conduit Corp. v. Indian Head, Inc., 486 U.S. 492 (1988); American Soc'y of Mechanical Eng'rs v. Hydrolevel Corp., 456 U.S. 556 (1982); Sessions Tank Liners, Inc. v. Joor Mfg., Inc., 17 F.3d 295 (9th Cir.) (misrepresentations to standard-setting organization on which government regulators routinely rely), cert. denied, $115 \mathrm{~S}$. Ct. 66 (1994). Another danger is that an accrediting body dominated by special interests will establish standards that, though apparently adopted in good faith, impede the marketing of desirable products. See, e.g., Structural Laminates, Inc. v. Douglas Fir Plywood Ass'n, 261 F. Supp. 154 (D. Or. 1966) (new type of plywood excluded from the market by restrictive requirements for essential seal of approval), aff'd, 399 F.2d 155 (9th Cir. 1968), cert. denied, 393 U.S. 1094 (1969). 
by the ABA. ${ }^{38}$ Private entities are regularly delegated similar responsibility for setting educational standards for most kinds of vocational training, permitting them to control not only the cost of entry into a field but also many characteristics of practitioners. ${ }^{39}$

The pending proposal by the ACPE to extend the length of pharmacist training illustrates tellingly how a private accreditor enjoying a publicly granted virtual monopoly over standard setting in a professional field can dominate the making of crucial policy, effectively preempting both legislative and consumer choice. Although one can debate whether or not future pharmacists should be required to have more training than the five-year minimum course required in the past, ${ }^{40}$ the processes currently in place for resolving this policy question lack democratic legitimacy. One source of difficulty is the DOE's recognition of the ACPE as the sole accreditor of pharmacy schools. More crucial, however, is the almost universal delegation to the ACPE by state legislatures or regulators of the authority to determine which training programs can qualify their graduates for licensure as pharmacists. This delegation makes it probable that, unless an effective lobbying campaign can be mounted, ${ }^{41}$ the ACPE, which is dominated by educators and practicing pharmacists, will be able to effect the policy change its members desire. ${ }^{42}$

Where government has effectively delegated policy choices to a professional group, antitrust law, as it now stands, can provide little relief. ${ }^{43}$ To be sure, government reliance on a private accreditor confers no automatic immunity from antitrust scrutiny. Courts would not, for example, infer from federal legislation authorizing reliance on a private accreditor a congressional intention to confer antitrust immunity on that accreditor. ${ }^{44}$ Courts have also refused to

38. Complaint at 13 (\$19), Massachusetts Sch. of Law at Andover, Inc. v. ABA (E.D. Pa. filed Nov. 23, 1993) (No. 93-6206) (on file with author).

39. For a survey of private credentialing and educational accrediting programs in health care, see Havighurst \& King, supra note 5, at 138-50.

40. See generally Henri R. Manasse, Jr. \& Pamela Ward Giblin, Commitments for the Future of Pharmacy: A Review and Opinion of the Pharm.D. Curricular Debate, 18 DRUG INTELLIGENCE AND Clinical PhaRmaCy 420 (1984).

41. In fact, such a campaign is under way. See Evaluation, supra note 12; Statement of American Stores Co. before the ACPE Hearing on the Pharm.D. Revisions, August 21, 1994 (on file with author).

42. For one scholar's perception of the antitrust implications of the comparable effort, early in this century, to extend the training of lawyers from two to three postgraduate years, see Harry First, Competition in the Legal Education Industry (pts. 1 \& 2), 53 N.Y.U. L. REV. 311 (1978) \& 54 N.Y.U. L. REV. 1049 (1979).

43. In the case of the ACPE's new standard, no antitrust challenge is likely from either educators or holders of the five-year degree. Alert to intraprofessional politics and perhaps also to antitrust risks, the ACPE has provided both ample notice of its intention and a long lead time before its new requirement takes effect. By that time, there will probably be no five-year programs to challenge a denial of accreditation and few graduates of such programs who have not been absorbed into the profession.

44. "Implied repeal" of the antitrust laws by another federal statute is not "lightly" inferred by courts in the absence of a "clear repugnancy" between the two statutory regimes. See, e.g., National Gerimedical Hosp. and Gerontology Ctr. v. Blue Cross, 452 U.S. 378, 388-89 (1981) (health planning legislation held not to create implied antitrust exemption); Gordon v. New York Stock Exch., 422 U.S. 659 (1975) (legislation providing for SEC oversight of stock exchange held to create implied antitrust 
immunize an accreditor solely because some agency of state government has delegated policymaking responsibilities to it. ${ }^{45}$ On the other hand, some accreditors whose policies are deferred to by government decisionmakers may enjoy immunity under the Noerr-Pennington doctrine, which immunizes from antitrust challenge otherwise lawful concerted efforts to influence government to take actions harmful to competition or to competitors of the lobbying interests. ${ }^{46}$ Thus, one court of appeals recently held that a competitor's egregious manipulation of a standard-setting program gave rise to no claim for antitrust damages because the only harms proved by the plaintiff were the direct

immunity); Silver v. New York Stock Exch., 373 U.S. 341 (1963) (implied immunity of stock exchange recognized only to the minimum extent necessary to make the regulatory scheme work); $c f$. Clark $\mathrm{C}$. Havighurst, Health Planning and Antitrust Law: The Implied Amendment Doctrine of the Rex Hospital Case, 14 N.C. CENT. L.J. 45 (1983). Not only is continued antitrust scrutiny of private accreditors entirely compatible with federal recognition of such accreditors, but Congress in conferring such recognition may have viewed antitrust oversight, perhaps mistakenly, as a valuable check against the exercise of undue power by such bodies.

45. The test for state-action immunity of a private entity has two parts: Not only must the state itself (not merely some agency acting in its name) have "clearly articulated" a policy at odds with federal antitrust policy, but it must also have provided for some kind of "active supervision" of the private actions taken pursuant to that policy. California Retail Liquor Dealers Ass'n v. Midcal Aluminum, Inc., 445 U.S. 97 (1980); see also City of Columbia v. Omni Outdoor Advertising, Inc., 499 U.S. 365 (1991); Patrick v. Burget, 486 U.S. 94 (1988). Thus, only a state statute (or state supreme court rule) expressly authorizing reliance on an identified private accreditor and also ensuring appropriate continuing supervision of the accreditor's performance would justify a judicial inference that the case is one in which Congress wished to defer to state sovereignty. See Hoover v. Ronwin, 466 U.S. 558 (1984) (committee of practicing lawyers administering bar examination for the state supreme court held to share the court's immunity from antitrust suits); see also Benitez v. Clark, 1987 U.S. Dist. LEXIS 6722 (N.D. Ill. 1987) (recognition of ABA accreditation by state supreme court held to insulate ABA from conspiracy charge brought by graduate of unaccredited school denied bar admission); Nordgren v. Hafter, 616 F. Supp. 742 (S.D. Miss. 1985). On the other hand, even public agencies charged with regulating professionals have been found guilty of antitrust violations when they acted anticompetitively without a clear legislative warrant. See, e.g., United States v. Texas State Bd. of Pub. Accountancy, 464 F. Supp. 400 (W.D. Tex. 1978); Massachusetts Bd. of Registration in Optometry, 110 F.T.C. 549 (1988). $A$ fortiori, private entities would probably not escape antitrust liability for acting anticompetitively without specific statutory authorization.

46. See United Mine Workers v. Pennington, 381 U.S. 657 (1965); Eastern R.R. Presidents Conference v. Noerr Motor Freight, Inc., 365 U.S. 127 (1961). The leading precedent on the application of this doctrine to standard-setting activities is Allied Tube \& Conduit Corp. v. Indian Head, Inc., 486 U.S. 492 (1988), which dealt with a conspiracy by several competitors to manipulate the internal processes of a standard-setting association to disadvantage a competing product. The Supreme Court rejected the defendants' argument that the Noerr doctrine protected their efforts to influence a "quasilegislative" private body whose "standards are widely adopted into law by state and local governments." Id. at 495. It implied, however, that standard setting affecting only government regulatory action might escape all scrutiny under the antitrust laws. See id. at 509-10 ("[W]e hold that at least where [a competitor participates in setting an anticompetitive standard, it] enjoys no Noerr immunity from any antitrust liability flowing from the effect the standard has of its own force in the marketplace."). And a later case has suggested that abuse of private accrediting may be of no antitrust consequence if it affects only public regulators. See infra note 47 and accompanying text. Recognizing an antitrust problem only when private actors are influenced would seem unjustified, however. Just as state action immunity applies only when a state has acted both definitively and responsibly (see supra note 45), the Noerr defense should not be available when the state has merely rubber-stamped a private accreditor's decision. After all, the state action and Noerr doctrines are both premised on the idea that government looks out for consumer welfare, making antitrust scrutiny unnecessary. When government has not acted deliberately and has allowed its processes to be perverted to private ends, federal antitrust policy should be given due effect. 
result of government action taken in reliance on the private standard. ${ }^{47}$ Under this ruling, antitrust law is essentially impotent to deter abuses of private accrediting where government is the sole executor of the accreditor's decisions.

Even if the antitrust laws applied with full force to private accreditors that have been officially recognized by government, however, one could still not count on antitrust courts to overcome many abuses of the authority so conferred. As stated earlier ${ }^{48}$ antitrust courts are not well suited to review the policy choices reflected in accrediting standards. Not only do courts lack the capacity to second-guess the technical judgments of accreditors, but they also have no clear warrant under the antitrust statutes to do more than verify that an accreditor's standards reflect an honest opinion or have a rational basis. ${ }^{49}$ Although it might seem that a conferral of power on an accreditor by government should trigger closer antitrust scrutiny, government's acceptance of the opinions of a private body does not alter the nature of that body or render an antitrust court a better or more appropriate judge of its policies. ${ }^{50}$ Antitrust review of the substantive validity or quality of an accreditor's standards or actions cannot (and should not be expected to) remedy the problem of unwise public delegation of policymaking responsibilities to private interests.

If antitrust law can neither prevent nor counteract the effects of a failure by the political-economic system to resolve an issue democratically either by legislative action or by consumer choice in the marketplace, then private interests will have many opportunities to use private accrediting to shape their legal, regulatory, and economic environments and to control the options available to consumers. To be sure, political institutions ultimately oversee the actions of private accreditors. But political pressures and the inherent limitations of collective action and public choice systematically incline such institutions toward serving special and majoritarian interests rather than the interests of individual consumers. Because high standards may be preferred both by industry interests (to limit entry) and by middle-class consumers (to reduce the cost and the risk of searching in a diverse market), political institutions are unlikely to object if an accreditor systematically rules off the market as substandard certain goods or services that a minority of consumers-especially low-income consumers-might desire. ${ }^{51}$ In view of these shortcomings of political institutions, there are good reasons to wish that

47. Sessions Tank Liners, Inc. v. Joor Mfg., Inc., 17 F.3d 295 (9th Cir. 1994), cert. denied, 115 S. Ct. 66 (1994). It is an open question, however, whether the standard-setting body that allowed its processes to be misused for anticompetitive purposes could have been enjoined to withdraw the tainted standard had it been a party to the action. See supra notes 13-14 and infra note 144 (discussing the Hydrolevel case, which imposed vicarious responsibility on an accreditor for an antitrust violation perpetrated by its agents).

48. See supra notes 20-21 and accompanying text.

49. See infra text accompanying notes 99-115.

50. See infra text accompanying note 92 .

51. Although it is customary to assume that higher standards are preferable to lower ones, such standards create significant burdens for all those who are forced either to pay for items or services of a higher quality than they desire to purchase or to forgo a needed item or service altogether. 
antitrust law could legitimately do more than it is currently doing to frustrate private interests in using publicly conferred accrediting powers to limit the terms on which competitors compete.

\section{Accrediting and Self-Regulation}

It is common to equate private standard setting and accrediting with industry or professional self-regulation. ${ }^{52}$ But, as illustrated below, literal self-regulation is not permitted by the antitrust laws. Thus, unless an industry group has special statutory authority, it cannot exercise direct regulatory control over its own members or over their competitors, suppliers, or customers. Unfortunately, however, even though antitrust law seemingly distinguishes between accrediting and actual self-regulation, it often fails to do so very clearly, with the result that the law's signals are mixed. Indeed, failure to discriminate clearly between procompetitive accrediting and anticompetitive self-regulation may cause some courts to approach accrediting too skeptically, while other courts may be too tolerant of efforts to exercise self-regulatory power for allegedly worthy purposes. Further questions are thus raised about the ability of antitrust law to encourage procompetitive accrediting while effectively policing abuses.

Self-regulation implies more than merely promulgating standards and certifying compliance with them. Regulation implies, in addition, actual enforcement of standards through the imposition of sanctions for noncompliance. An industry group would violate elementary antitrust principles, however, if it sponsored, without. statutory authority, a collective agreement to boycott anyone who did not follow its standards voluntarily. ${ }^{53}$ The law also prohibits naked agreements among competitors to sell only products meeting agreed-upon

52. See, e.g., American Soc'y of Mechanical Eng'rs, Inc. v. Hydrolevel Corp., 456 U.S. 556, 570 (1982), in which the Supreme Court characterized the defendant (ASME), a typical standard-setting and certifying organization, as "'in reality an extra-governmental agency, which prescribes rules for the regulation and restraint of interstate commerce"' (quoting Fashion Originators' Guild of Am. v. FTC, 312 U.S. 457, 465 (1941)). The Court's apparent equation of ASME with the defendant in Fashion Originators' is insupportable, however, for reasons to be developed in the text. Unlike ASME, that organization had gone beyond merely expressing the opinion of its members concerning the products of their competitors and had organized an actual boycott of retailers carrying unapproved merchandise. Although ASME had taken no coercive action to enforce its standards (its malfeasance was of a different kind), the Court was apparently impressed that "ASME wields great power in the nation's economy." Id. at 570. But even though the Supreme Court has thus seemingly equated private accrediting with self-regulation solely on the basis of its de facto significance in the marketplace, accreditation is not the equivalent of regulation because it lacks coercive sanctions and, unlike licensure, is not itself exclusionary.

53. See, e.g., Fashion Originators', 312 U.S. at 465 ("[T]he combination is in reality an extragovernmental agency, which prescribes rules for the regulation and restraint of interstate commerce, and provides extra-judicial tribunals for the determination and punishment of violations, and thus 'trenches upon the power of the national legislature and violates the statute.'") (quoting Addyston Pipe \& Steel Co. v. United States, 175 U.S. 211, 242 (1899)); see also Silver v. New York Stock Exch., 373 U.S. 341 (1963) (recognizing limited authority for stock exchange, charged by statute with selfregulatory responsibilities, to organize otherwise unlawful boycott against securities dealers not meeting exchange standards). 
standards. ${ }^{54}$ On the other hand, collaborating merely to develop standards and to verify whether individual firms are meeting them would not curtail anyone's competitive freedom. Indeed, such collaboration is not only compatible with the maintenance of competition in the market as a whole, but it is facially procompetitive in providing information potentially useful to market actors. Collaboration in accrediting neither requires individual firms to surrender their competitive freedom nor "deprives the marketplace of the independent centers of decisionmaking that competition assumes and demands." 55

Many antitrust suits against accrediting bodies have involved not accrediting alone but conduct more directly harmful to competition. ${ }^{56}$ In the Radiant Burners case, for example, the Supreme Court upheld the plaintiff's complaint by construing it to allege a "conspiratorial refusal [by certain members of the accrediting organization] to supply gas for use in the plaintiff's [unapproved product]. .57 Scholars and others regularly misread this case, however, by identifying as the unlawful boycott, not the concerted refusal to supply gas, but the allegedly unreasonable denial of the seal of approval. ${ }^{58}$ The confusion thus introduced may be more than semantic. ${ }^{59}$ Indeed, characterizing accrediting

54. Although antitrust offenses are rarely characterized in just these terms, many violations could be. For example, several cases have condemned naked agreements fixing the contract terms on which motion pictures are licensed to exhibitors. Interstate Circuit v. United States, 306 U.S. 208 (1939); United States v. First Nat'l Pictures, 282 U.S. 44 (1930); Paramount Famous Lasky Corp. v. United States, 282 U.S. 30 (1930). For another case condemning an actual agreement by competitors to standardize their services, see FTC v. Indiana Fed'n of Dentists, 476 U.S. 447, 452 (1986) (FTC found "competition among dentists for patients would have tended to lead dentists to compete with respect to their policies in dealing with patients' insurers"; Court upheld finding that agreement on such policies was unlawful). Competitor independence in deciding what goods or services to offer consumers would seem to be a critically important dimension of competition and, as such, worthy of antitrust protection comparable to that provided against price fixing, market division, and true boycotts.

55. Copperweld Corp. v. Independence Tube Corp., 467 U.S. 752, 769 (1984).

56. See supra notes $17 \& 18$.

57. Radiant Burners, Inc. v. Peoples Gas Light \& Coke Co., 364 U.S. 656 (1961).

58. LAWRENCE SULLIVAN, ANTITRUST \$86, at 243 (1977) (misreading case as treating manufacturing members of AGA as "the perpetrators of the "boycott" and the offense as "concertedly inducing the agency not to supply to plaintiff the approval [it needed]"); see also Virginia Academy of Clinical Psychologists v. Blue Shield, 624 F.2d 476, 484 (4th Cir. 1980); STANDARDS AND CERTIFICATION, supra note 19, at 248-49; BASIL J. MEZINES, TRADE ASSOCIATIONS AND THE ANTITRUST LAWS A26 (2d ed. 1993) (viewing allegation of arbitrary application of nonobjective standard as key to pleading of illegal boycott); Joseph Bauer, Professional Activities and the Antitrust Laws, 50 NOTRE DAME L. REV. 570 (1975).

59. Strictly speaking, group boycotts are agreements by multiple actors to make collective rather than independent judgments about the suppliers or customers with whom they each will deal. Although accrediting involves collective judgments by competitors, an accrediting body can function without binding its members to act on the judgments it makes. Because accrediting has a procompetitive purpose not requiring interference with the independence of its sponsors, it is fundamentally distinguishable from a true boycott and cannot be condemned without evidence of an adverse effect on competition. See infra note 60 . To analogize competitor-sponsored accrediting to a boycott, therefore, is not only unhelpful, but it is also apt to send misleading signals to judges and lawyers. Unfortunately, courts have now gone along in characterizing refusals by competitor-controlled entities to deal, admit to membership, or accredit as "group boycotts" or "concerted refusals to deal." The Supreme Court did so, however, only at a late date-and with evident reservation about the aptness of the terminology. See Northwest Wholesale Stationers, Inc. v. Pacific Stationery \& Printing Co., 472 U.S. 283 (1985) (case involving exclusion of firm from purchasing cooperative said to raise "questions 
decisions as possible group boycotts may cause courts to see accrediting as a greater threat to competition than it actually is. Similarly, if potentially procompetitive activities such as accrediting are lumped under the boycott label, a court confronting an accrediting program might fail to single out and condemn an accompanying boycott and might instead give rule-of-reason treatment to the program as a whole. ${ }^{60}$ The terminological confusion makes it harder to conclude that antitrust law is well attuned to fostering procompetitive accrediting while simultaneously preventing boycotts in aid of whatever worthy purposes the accreditors may allege. ${ }^{61}$

Confusion also surrounds the legality of agreements by competitors to abide by accrediting standards in designing their products. To be sure, a naked agreement among industry members not to produce certain products would normally violate the Sherman Act. ${ }^{62}$ But even though such an overt anticompetitive agreement is distinguishable in theory from accrediting itself, the distinction might seem more conceptual than helpful in deciding particular cases. Indeed, it is hard to ignore the reality that, when industry-wide standards are agreed upon, there is probably also some implicit understanding or expectation that they will be followed in practice. Thus, the Supreme Court in the 1988 Allied Tube case observed that "agreement on a product standard is, after all, implicitly an agreement not to manufacture, distribute, or purchase certain types of products."63 The aforementioned unwillingness of courts to distinguish sharply between accrediting and group boycotts probably reflects a similar intuition that the distinction, while possibly valid, is too technical to be useful in practice.

Despite the seeming fineness of the distinction between accrediting and selfregulation, however, courts should not ignore it. Precisely because accrediting programs present anticompetitive risks while also having procompetitive potential, antitrust courts are obliged to apply the rule of reason to maximize the net benefit of such programs to competition and consumer welfare. ${ }^{64}$ One

as to when per se analysis is appropriately applied to joint activity that is susceptible of being characterized as a concerted refusal to deal" (emphasis added)).

60. Contrary to a common view, the harm to competition that should concern an antitrust court lies in the naked agreement to boycott itself, not in its purpose or in its impact on third parties. Thus, a true boycott should be condemned without regard to whether it was effective or can be shown to have an adverse effect on consumer welfare, broadly defined. Antitrust law should be concerned only that buyers and sellers face an unrigged market in which their suppliers and customers make independent, not collective, decisions not only about pricing but also about those with whom they will deal. See generally Klor's v. Broadway-Hale Stores, 359 U.S. 207, 213 (1959) (speaking of a true boycott, the Court said, "This combination takes from Klor's its freedom to buy appliances in an open competitive market and ... deprives the manufacturers and distributors of their freedom to sell to Klor's ....").

61. The most egregious recent deviations from the rule that clear trade restraints cannot be justified by worthy purposes have been the Wilk case, which was described in note 32 supra and probably overruled by later cases, see supra note 33, and the Brown University case, see supra notes $24,33$.

62. See supra note 52 .

63. Allied Tube \& Conduit Corp. v. Indian Head, Inc., 486 U.S. 492, 500 (1988); see also id. at 507 ("[A]ny agreement to exclude polyvinyl chloride conduit from the Code is in part an implicit agreement not to trade in that type of electrical conduit.").

64. See infra notes 69-75 and accompanying text. 
element of the rule of reason is the requirement that competitors collaborating for a procompetitive purpose must arrange their undertaking so as to pose no unreasonable hazards to competition. ${ }^{65}$ Under this "less-restrictive-alternative" requirement, collaborators in accrediting should be expected to retain as much independence as possible in deciding what suppliers to patronize, what customers to serve, and what products or services (standard or nonstandard, accredited or unaccredited) to offer. Because any express agreement to abide by the accreditor's standards, or to boycott those who do not, cannot be defended as ancillary to the larger accrediting program, all such agreements should be unlawful per se.

To be sure, a competitor adversely affected by an accrediting program might allege a conspiracy to honor or enforce a particular standard without any direct evidence of an express agreement to do so. To the extent that such a conspiracy is inferable from circumstantial evidence (including uniform, consciously parallel behavior honoring the standard ${ }^{66}$ ), allegations of this kind would open accreditors to significant legal risks, chilling the production of procompetitive information. Thus, unless courts can effectively protect accreditors against unfounded allegations of conspiracy, private accrediting by competitor-controlled organizations could be a legally hazardous activity. The Supreme Court's dicta in Allied Tube is best understood as an acknowledgment of the difficulty of determining the actual scope of the collaboration in these cases. Indeed, the Court's quoted observation makes doctrinal sense only if read as an appreciation that some degree of common understanding with respect to compliance is inherent in the act of setting standards and cannot, without more, violate the Sherman Act. $^{67}$

65. See generally AREEDA, supra note 1, II 1505, at 383-89. See also Kreuzer v. American Academy of Periodontology, 735 F.2d 1479, 1494-95 (D.C. Cir. 1984). In general, a demonstration that the parties could have achieved their legitimate objectives in a manner less hazardous to competition may establish either that the parties' true purposes were not what they claim or that their conduct was unreasonably restrictive and therefore unlawful. A danger is that courts or law enforcers may be unreasonably demanding in their exercise of hindsight, using small deviations from an ideal arrangement to penalize desirable conduct.

66. So-called conscious parallelism alone is not sufficient to warrant a finding of concerted action. E.g., Theater Enter. v. Paramount Film Distrib. Co., 346 U. S. 537 (1954) (parallel refusals to offer firstrun films for exhibition in plaintiff's theater held not enough when evidence suggested that defendants had independent reasons for refusal). Nevertheless, an industry-wide policy of acting for mutual rather than individual advantage, such as in refusing to take advantage of potentially profitable market opportunities in apparent reliance on competitors to act similarly, could be evidence of an unlawful conspiracy.

67. In general, antitrust plaintiffs, to establish a conspiracy, "must present evidence "that tends to exclude the possibility' that the alleged conspirators acted independently." Matsushita Elec. Indus. Co. v. Zenith Radio Corp., 475 U.S. 574, 588 (1986) (stating test for summary judgment in conspiracy cases) (quoting Monsanto Co. v. Spray-Rite Service Corp., 465 U.S. 752, 764 (1984)). Because well-conceived accrediting standards are quite likely to be universally honored, the Allied Tube court's acknowledgement of the likelihood of conscious parallelism should help future defendants in accrediting cases obtain summary judgment-without suggesting tolerance for explicit agreements to abide by or enforce standards. 
Doctrinally, the point is simply this: Competitors are permitted to collaborate for a procompetitive purpose only if they employ means that are no more dangerous to competition than is reasonably necessary to accomplish their legitimate objectives. An overt agreement to honor or enforce a standard would therefore be illegal. But as long as collaborators in accrediting respect the lessrestrictive-alternative requirement by avoiding explicit anticompetitive agreements and by disclaiming any intention to curb independent action, any remaining hazard to competition should be viewed, under the Allied Tube dicta, as a lawful ancillary restraint. ${ }^{68}$

Most accrediting bodies in fact limit their role to developing standards and to granting and withholding accreditation and do not appear to broker anticompetitive agreements or to enforce their standards in improper ways. Under current law, therefore, their antitrust status depends upon how the courts view accrediting alone-the subject of the next part of this article. Nevertheless, the inherent tendency of accrediting to curtail the independence of participating competitors remains a significant concern. Later discussion will suggest some doctrinal innovations that would undermine the dominance of particular accreditors, thus curbing the regulatory tendencies inherent in private accrediting. The antitrust enforcement agenda to be proposed would greatly strengthen the ability of antitrust law to foster procompetitive accrediting and to limit opportunities for abuse.

\section{III}

\section{ANAlyzing the Competitive EFFeCts of Private ACCREditing}

Any effort to frame an antitrust complaint against or to defend a particular accrediting standard or accrediting action quickly reveals difficulties with the rule of reason that courts are expected to employ in detecting unlawful restraints of trade. ${ }^{69}$ Under the rule of reason, courts are to condemn competitor collaboration only if, after appropriate scrutiny, it is found to restrain trade in fact. Certain concerted actions-such as agreements on prices, on the markets that each competitor will serve, or on the suppliers or customers with whom each competitor will deal-are characterized as restraints per se; that is, they are condemned automatically because harm to competition is so highly probable that further factual inquiry to demonstrate actual harm is unnecessary-especially in light of the need for bright-line rules to deter antisocial

68. See infra note 74 and accompanying text.

69. On its face, the Sherman Act presents the interpretational problem that, in condemning "every" restraint of trade, it seems to condemn virtually all cooperation between competitors. The scope of this condemnation therefore had to be sorted out in a number of early cases in which the Supreme Court eventually announced the rule of reason. Chicago Bd. of Trade v. United States, 246 U.S. 231, 238 (1918); United States v. American Tobacco Co., 221 U.S. 106, 179-80 (1911); Standard Oil Co. v. United States, 221 U.S. 1, 59-68 (1911). 
conduct. $^{70}$ Concerted action not falling in a per se category, however, must be evaluated at greater length.

Although the rule of reason does not lend itself to mechanical application when no per se offense can be identified, a basic analytical framework can be discerned. The objective of the inquiry remains the discovery of the actual or probable net effect of the concerted action on competition as a process for promoting efficiency and enhancing consumer welfare. Adverse effects on individual competitors, as such, are not an antitrust concern since competition is expected to yield losers as well as winners; whether the competitive process has been impaired is a distinct question. Moreover, the rule of reason does not invite appraisal of reasonableness in some public-policy sense; instead, the Sherman Act, by establishing a conclusive presumption in favor of competition and against concerted private action subverting competition, leaves a court no warrant for asking in a particular case whether trade was restrained for a worthy or an unworthy social purpose. ${ }^{71}$ In general, courts must keep their eyes on the ball of competition and not be distracted by fairness concerns or by value judgments about the parties, their motives, or particular business practices.

When seeking to distinguish lawful from unlawful concerted action, antitrust courts seem to consider four discrete factors: (1) the purpose of the particular arrangement; (2) the market power of the collaborating parties; (3) whether a less restrictive alternative was available to the parties as a means to accomplish their legitimate purposes; and (4) the arrangement's specific procompetitive (efficiency-enhancing) and anticompetitive effects. ${ }^{72}$ With respect to purpose, the crucial question is whether the objective pursued could be achieved only by attenuating market forces. If so, the restraint would be characterizable as a "naked" one, making it a good candidate for condemnation. ${ }^{73}$ If, however, any adverse effect on competition in the market as a whole is unintended and merely incidental to the pursuit of a legitimate objective (such as achieving efficiency or producing a new product), the restraint would be classified as

70. See Arizona v. Maricopa County Medical Soc'y, 457 U.S. 332, 343-48 (1982); Northern Pacific Ry. v. United States, 356 U.S. 1, 5 (1958); United States v. Socony-Vacuum Oil Co., 310 U.S. 150, 218 (1940).

71. See National Soc'y of Professional Eng'rs v. United States, 435 U.S. 679, 693-96 (1978) (rejecting evidence that restraint on price competition promoted public safety by discouraging cut-rate engineering work); United States v. Trenton Potteries Co., 273 U.S. 392, 396-401 (1927) (concluding reasonableness of fixed prices is not a defense to charge of price fixing). But see United States v. Brown Univ., 5 F.3d 658 (3d Cir. 1993) (allowing proof of "noneconomic justifications" to justify naked fixing of scholarship terms).

72. For a suggested analytical approach as applied in a somewhat related context, see Clark C. Havighurst, Professional Peer Review and the Antitrust Laws, 36 CASE W. RES. L. REV. 1117, 1118-23, 1130-33 (1986). For the FTC's analytical approach, see In the Matter of Massachusetts Bd. of Registration in Optometry, 110 F.T.C. 549, 604 (1988). It is not known how the FTC would apply its approach to private accrediting.

73. To be sure, the courts have never declared all naked restraints illegal per se. But neither have they made it clear how a naked restraint-that is, one with an objective dependent upon the suppression of competition-could escape condemnation. See generally AREEDA, supra note 1, q 1504, at 382.83 (discussing possible market-failure rationale for upholding a restraint that "actually moves market performance closer to the competitive result"). 
"ancillary" and would be scrutinized more closely. ${ }^{74}$ An ancillary harm to competition can pass muster under the rule of reason, however, only if the restraint causing it was no more anticompetitive than reasonably necessary to accomplish the parties' procompetitive purpose and if the entire arrangement had a net effect compatible with competition (understood as a dynamic process generally beneficial to consumers). The element of market power may be helpful in identifying arrangements that can be excused from more demanding analysis, since, without market power, the parties can have no harmful effect on competition. ${ }^{75}$ Only when the collaborators both possess market power and neglected a less restrictive way to pursue their procompetitive purpose would it be necessary for a court to balance good and bad effects to determine the net impact of their actions on competition and efficiency.

These doctrinal principles and tests have not been easy for courts to apply in accreditation cases. The central conceptual problem is that, although an accreditation program can certainly affect, perhaps fatally, the prospects of some competitors or products, its effects are indirect and depend on how the universe of independent decisionmakers react to the accreditor's standards and accrediting decisions. In other words, it is far from clear that accrediting alone, even though it involves concerted action and may affect market outcomes, affects competition itself. The discussion below demonstrates that courts have yet to achieve clarity on this elementary question.

\section{A. Procompetitive Concerted Action or Restraint of Trade?}

As noted earlier, ${ }^{76}$ a conceptually important distinction exists between an industry-sponsored program to verify whether individual firms are meeting collectively promulgated standards and a naked agreement by competitors either to produce only according to such standards or to enforce them against others by collective action. Collective accrediting standing alone, therefore, may not constitute a restraint of trade of any kind, reasonable or unreasonable. Thus, a doctrinally rigorous court might be slow to apply the restraint-of-trade label

74. The leading authority on the legality of ancillary restraints is still the opinion of Judge William Howard Taft in United States v. Addyston Pipe \& Steel Co., 85 F. 271 (6th Cir. 1898), aff', 175 U.S. 211 (1899). Although courts have not uniformly employed this terminology, the dichotomy between naked and ancillary restraints serves well for analytical purposes. For modern discussions and applications of the rule of reason, see FTC v. Indiana Fed'n of Dentists, 476 U.S. 447, 459-65 (1986); Northwest Wholesale Stationers, Inc. v. Pacific Stationery \& Printing Co., 472 U.S. 284, 294-96 (1985); NCAA v. Board of Regents, 468 U.S. 85, 100-03 (1984); Broadcast Music, Inc. v. CBS, 441 U.S. 1, 13-16 (1979); National Soc'y of Prof'l Eng'rs v. United States, 432 U.S. 679 (1978).

75. Because the complexity of markets may make it difficult to prove or disprove actual anticompetitive effects (such as reduction of output, noncompetitive prices, or artificial effects on the quality of goods or services), proof of the defendants' market power (or lack of it) often helps to establish the likelihood of adverse effects. See generally AREEDA, supra note 1, II 1511, at 429, $432-33$ (suggesting use of market power as a "surrogate for detrimental effects," with the required proof of it varying with the perceived seriousness of the restraint and the court's suppositions about the context). See also Indiana Fed'n of Dentists, 476 U.S. at 460-61; Brown Univ., 5 F.3d at 668-69.

76. See supra text accompanying notes 52-68. 
to accrediting activities, treating that label (as the statute does) as more nearly the end of the inquiry than the beginning. ${ }^{n}$

Indeed, such a court might not apply the restraint-of-trade label at all. Accreditation can be seen, after all, as nothing more than the expression by an authoritative private body of its considered opinion of practices or products covered by its standards or of individual competitors in the accredited field. These opinions serve a distinctly procompetitive purpose, assisting purchasers and others in making judgments about the desirability of particular goods or services or the competence of certain suppliers. Consumer information on such matters is a so-called "public good" and, as such, is chronically underproduced in competitive markets, making the public necessarily dependent for crucial information on such self-interested sources or media as salesmen, sales literature, commercial advertising, and competitor-sponsored accrediting programs. $^{78}$ Given the procompetitiveness of accrediting as an informational activity, it is not obvious how a careful court could find in the Sherman Act a warrant for scrutinizing accrediting standards or an accreditor's action in applying them.

Perceiving that the collective statement of an opinion, standing alone, does not harm competition, Judge Easterbrook stated the following "truism" at the outset of an opinion for the court of appeals in a 1989 case finding no antitrust violation in a professional society's publication of its poor opinion of a new service being offered by certain competitors: "There can be no restraint of trade without a restraint." 79 The court then went on to hold that "when a trade association provides information ... but does not constrain others to follow its recommendations, it does not violate the antitrust laws." 80 Thus, if the alleged adverse effects of an accrediting program flow only from actions taken by others in reliance on the accreditors' opinion, it can be contended with some force that trade has not been restrained at all. Indeed, it might be more accurate to say in such a case that the market, provided with new information, worked just as it is supposed to do and to conclude that disadvantaged competitors should fight back in the marketplace, not in the courts.

Judge Easterbrook reinforced the latter point by evoking a principle found in freedom of speech cases:

The Academy's declaration affected only the demand side of the market, and then only by appealing to consumers' (and third-party payors') better judgment. If such

77. Although it is conventional to say that the Sherman Act condemns only "unreasonable" restraints, the statute literally requires that concerted action be characterized as a restraint only after it has failed the rule of reason test. In any event, it may be a mistake to jump to the question of reasonableness without first ascertaining that the conduct under scrutiny can fairly be characterized as a restraint.

78. See supra note 6.

79. Schachar v. American Academy of Ophthalmology, 879 F.2d 397, 399 (7th Cir. 1989).

80. Id. at 399 (citing Consolidated Metal Prods., Inc. v. American Petroleum Inst., 846 F.2d 284 (5th Cir. 1988)). 
statements should be false or misleading or incomplete or just plain mistaken, the remedy is not antitrust litigation but more speech-the marketplace of ideas. ${ }^{81}$

And, indeed, the First Amendment does suggest, even if it does not actually supply, a reason for courts to go slow in penalizing an accreditor for publishing a controversial standard or a debatable opinion concerning an individual competitor. As collective speech, an accreditor's actions can be analogized to, and might even be characterized as, "commercial speech," which enjoys some, though limited, constitutional protection. ${ }^{82}$ Although such protection has heretofore been given only to various kinds of commercial advertising, ${ }^{83}$ competitor-sponsored accreditation also involves the publication of possibly selfinterested information and opinions that are potentially harmful to competitors while also being potentially useful to consumers. In any event, whether or not private accreditors actually enjoy constitutional protection, ${ }^{84}$ antitrust policy alone should inspire courts to value accreditation for reasons similar to those underlying first amendment protection of commercial speech. ${ }^{85}$

Although there are many good reasons for not treating private accrediting as a restraint of trade, many courts examining accrediting programs under the antitrust laws have simply assumed that competitor-sponsored accrediting constitutes a restraint subject to a reasonableness test. ${ }^{86}$ Such an approach to applying the Sherman Act to accrediting appears most clearly in a 1983 FTC staff study of product standards and certification: "The standard is the product

81. Id. at 400 . Other courts have also noted the value and the effectiveness of the marketplace as a forum for resolving trade-offs of the kind that accreditors encounter. E.g., Consolidated Metal, 846 F.2d at 296 (footnote omitted):

Although there is some danger that API could use its influence to reduce competition, this danger is small so long as users rely voluntarily upon the API monogram. If users choose freely to rely on API approval, API has influence principally because it has done a good job evaluating products. If API fails to evaluate products accurately, consumers free to sample nonmonogrammed goods will gradually discover the monogram's diminished usefulness and cease relying upon it. Thus, the greatest threat to competition is in the short run, before a significant number of buyers shop around.

82. See Central Hudson Gas \& Elec. Corp. v. Public Serv. Comm'n of N.Y., 447 U.S. 557, 566 (1980) (stating modern four-part test of commercial speech protection); Virginia State Bd. of Pharmacy v. Virginia Citizens Consumer Council, Inc., 425 U.S. 748 (1976) (striking down prohibition on pharmacists' advertising of prescription drug prices).

83. See Bolger v. Youngs Drug Prods. Corp., 463 U.S. 60, 66-67 (1983) (listing factors identifying commercial speech).

84. One district court rejected an accreditor's argument that its policies, because they "rest on matters of opinion, ... cannot be constitutionally evaluated by the Court." Welch v. American Psychoanalytic Ass'n, 1986-1 Trade Cas. (CCH) q 67,037 (S.D.N.Y. Apr. 4, 1986).

85. See, e.g., Virginia Citizens, 425 U.S. at 765:

So long as we preserve a predominantly free enterprise economy, the allocation of our resources in large measure will be made through numerous private economic decisions. It is a matter of public interest that those decisions, in the aggregate, be intelligent and well informed. To this end, the free flow of commercial information is indispensable.

See also Havighurst \& King, supra note 5, at 194-97 ("[A] sensitive reading of antitrust law suggests that it shares the first amendment's libertarian roots and needs no help from the Constitution to accommodate free speech concerns.").

86. E.g., Paralegal Inst., Inc. v. ABA, 475 F. Supp. 1123 (1979) (court assumed, without addressing, the applicability of the antitrust laws to the accreditation of paralegal training programs). 
of joint action and restrains trade by diverting business from one competitor to another. . . . Standards activities by their nature restrain trade . ..."87 Many courts have analyzed competitor-sponsored accrediting under a comparable assumption. Some have even singled out the effort to influence independent decisionmakers to patronize only accredited suppliers as the root of the antitrust problem, apparently sensing that such selling efforts are somehow a threat to, rather than the essence of, competition. ${ }^{88}$ Courts with this particular blind spot would also be inclined to find the procompetitive aspect of accrediting not in its informational features alone but in its promotion of some worthy social objective, such as higher quality in products or services. ${ }^{89}$ Indeed, if the goal seems worthy, such courts may not be duly vigilant against agreements nakedly foreclosing producer independence or preempting consumer choice.

For courts that view accrediting as inherently trade-restraining, the critical factor in each case is likely to be the degree of disadvantage suffered by unaccredited competitors or products. ${ }^{90}$ To be sure, it is not always clear whether such courts believe in fact that all accrediting restrains trade, with the reasonableness of the restraint depending on how much weight the market accords it, or whether, instead, they view accrediting as a restraint only if the

87. STANDARDS AND CERTIFICATION, supra note 19, at 275-76; see also id. at 247 ("Evidence on the rulemaking record ... points out the restraint on market forces that standards can cause due to reliance by buyers, government regulatory agencies, and others."). The bureau that prepared this report is not, it should be noted, the Commission's antitrust arm.

88. See, e.g., Kreuzer v. American Academy of Periodontologists, 735 F.2d 1479, 1496, 1494 (D.C Cir. 1984) ("[A]bsent publication of the AAP Membership Directory [a listing excluding the plaintiff] as a referral guide, there would have been no concern of an antitrust violation"; "When the economic self-interest of the [accreditors] and its proffered justifications merge the rule of reason will seldom be satisfied."); Daniel v. American Bd. of Emergency Medicine, 802 F. Supp. 912, 926 (W.D.N.Y. 1992) (holding that a restraint of trade was pleaded by a complaint alleging "that the Board furnishes lists of Diplomates to other physicians, hospitals, medical schools, and the public in order to induce such parties to employ Board-certified physicians as opposed to non-Diplomates, based on the Board's alleged representation that Diplomates are the most highly qualified to practice emergency medicine").

89. Enhancing the quality of services has often been identified as a potential procompetitive benefit of concerted action in the market for health and educational services. See, e.g., Kreuzer, 735 F.2d at 1494 (recognizing claim of "patient care motive" and "improve[d] . . quality of care of periodontal patients" as possible justification for accrediting standard); Paralegal Institute, 475 F. Supp. at 1130-31 (approving accreditation scheme in part because of its value in improving training of paralegals). For a full analysis of quality as a defense, see Thomas E. Kauper, The Role of Quality of Health Care Considerations in Antitrust Analysis, 51 LAW \& CONTEMP. PROBS. 273, 340 (Spring 1988):

Conduct that promotes efficiency, ameliorates the effects of market failures or imperfections, or increases quality rivalry among providers is, to this extent, procompetitive and may improve quality of care by enhancing the competitive process. Any further accommodation of qualityof-care concerns is a direct challenge to the central role of the market in the determination of quality, and therefore to the relevance of antitrust itself.

90. Some decisions suggest that there may be a kind of sliding scale that allows courts to relax their vigilance whenever the disadvantage suffered by unaccredited competitors or products is not decisive in the marketplace but requires courts to tighten scrutiny in proportion to the de facto influence of the accreditor's program. Cf. Marjorie Webster Jr. College, Inc. v. Middle States Ass'n of Colleges \& Secondary Sch., Inc. 432 F.2d 650, 655-58 (D.C. Cir.) (illuminating analysis in common-law rather than antitrust context), cert. denied, 400 U.S. 965 (1970), discussed in Havighurst \& King, supra note 5, at 164-66; see also Judy Whalley, Crossing the Line-When Can Standards Create Antitrust Problems?, ASTM STANDARDIZATION NEWS (Jan. 1990) (Justice Department official stresses accreditor's ability to control access to market as key fact in antitrust analysis). 
accreditation in question is crucial to a competitor's survival..$^{91}$ In either case, however, no distinction is drawn between a restraint and its effects, implying that it is only the effects that matter, not the manner in which they are achieved. Yet de facto exclusionary effects should have no bearing unless the essential restraint of trade is present. For example, even if a government regulatory agency withholds crucial recognition from potential competitors in reliance on an accrediting body, that reliance alone does not warrant antitrust scrutiny of the accreditor's standards or actions; the restraint, if any, lies in the regulatory scheme, not in the accrediting program on which it relies. ${ }^{92}$ Indeed, to impose antitrust risks on an accreditor solely because it has become highly influential in its field would be to penalize it for its success in earning the confidence of others. Antitrust law is not intended to punish a firm or joint venture simply because it produces a successful product-in this case, advice that third parties voluntarily follow. As Judge Easterbrook opined, "an organization's towering reputation does not reduce its freedom to speak out."

Antitrust courts have thus approached competitor-sponsored standard setting and accrediting from two distinct perspectives, some viewing it as essentially procompetitive informational activity and others treating it as anticompetitive concerted action requiring justification as a reasonable restraint of trade. It seems probable, however, that courts are more likely to frame their inquiries correctly if they remain mindful that a collective program designed only to inform and thereby to influence consumers and their agents is essentially a procompetitive, not an anticompetitive, endeavor.

91. See, e.g., Paralegal Institute, 475 F. Supp. at 1130 ("[T]he ABA Guidelines and accreditation program are reasonable as they affect the paralegal field. They are hardly restraints at all. .. The court is satisfied that the accreditation program does not impose any unreasonable burdens on paralegal schools."); Daniel, 802 F. Supp. at 921 ("The potential for unreasonably restricting the market for Board-certified emergency physicians and the allegations of anti-competitive restrictions on the availability of Board-certified emergency treatment providers is what this case is fundamentally about.").

92. Such reliance is not essentially different in kind or in its antitrust significance from voluntary acceptance of accrediting by private entities. It is also subject to change through the political process-again, the marketplace of ideas-where the problem (if any) originated. See Zavaletta v. ABA, 721 F. Supp. 96, 98 (E.D. Va 1989) (holding that accreditation of law schools by the ABA was not a restraint because "the ABA merely expresses its educated opinion-at the school's own request-about the quality of the school's program. This information is provided to state supreme courts and bar examiners, who have the sole power to determine if a school's graduates are entitled to sit for the bar examination or practice in their states. ... [The states] are free to heed the ABA or not, as they choose."); $c f$. McKeesport Hosp. v. Accreditation Council for Graduate Med. Educ., 1994 U.S. App. LEXIS 10842 (3d Cir. 1994) (state board's reliance held not to convert ACGME into state actor subject to constitutional due process requirements).

Not only does the Noerr-Pennington doctrine permit accreditors to cultivate government support and acceptance of their accrediting monopoly, but that doctrine and the principles of state-action immunity might be read, in spirit at least, to preclude stepping up an antitrust attack on an accreditor based simply on its success in getting government to recognize its program. See supra note 90 . For the surprising view that the Noerr-Pennington doctrine immunizes an accreditor or other wrongdoer to the extent that government rather than the marketplace gives effect to its abuses, see supra note $46 \& 47$ and accompanying text.

93. Schachar v. American Academy of Opthamology, Inc., 870 F.2d 397, 399 (7th Cir. 1989). 


\section{B. The Scope of Antitrust Review of Accrediting Standards and Actions}

Even courts that view private accrediting as a fundamentally procompetitive activity are unlikely to excuse entirely from antitrust scrutiny an accrediting program that exercises substantial influence in its field. Thus, whenever a private accreditor is in a position to dictate standards in a particular field (rather than merely to suggest them), most courts would probably feel justified in invoking the antitrust laws as the predicate for scrutinizing its policies for substantive merit. Nevertheless, a precise legal theory under which an antitrust court might intervene in private accrediting must still be identified.

Judicial oversight of private accrediting under the Sherman Act can be rationalized in the following terms: Even though private accrediting can be beneficially and procompetitively informative, it also lends itself to unfair or deceptive labeling that can create market power in excess of that which would flow from the publication of truthful information and honest advice. ${ }^{94}$ Some risk of anticompetitive abuse is therefore an inherent feature of any accrediting program. Because competitor collaboration in accrediting has the potential to increase market power by increasing concentration or raising entry barriers in the market in which the collaborators compete, it should be subject to scrutiny to determine whether procompetitive or anticompetitive effects predominate. ${ }^{95}$ As to possible first amendment concerns, some cases will present a "clear and

94. See generally Havighurst \& King, supra note 5, at 150-201 (discussing "unfairness and deception in private credentialing").

95. Note that "the dominant antitrust concern [here] is not with restrictions among the collaborators themselves but with the possibility that the collaborators will use the [accrediting] scheme unfairly to injure their competitors." Id. at 173. Thus, "reference should be had not to the law of boycotts but to the body of case law that deals with the use of legitimate joint ventures to disadvantage nonparticipants unfairly." Id. at 176 . For the argument that private accrediting should be analogized to the kinds of competitor collaboration and exclusion of competitors that have been scrutinized under the so-called essential-facilities doctrine, see id. at 176-77. This doctrine, exemplified in Associated Press v. United States, 326 U.S. 1 (1945), and United States v. Terminal R.R. Ass'n of St. Louis, 224 U.S. 383 (1912), allows courts to scrutinize the rules excluding certain competitors from participation in otherwise procompetitive joint ventures organized by others. See also United States v. Realty MultiList, Inc., 629 F.2d 1351 (5th Cir. 1980) (scrutinizing, perhaps too closely, rules governing membership in realtors' multiple listing service), discussed in AREEDA, supra note $1,71508 \mathrm{~b}$, at 404 . Although Areeda is content to analyze all concerted action simply in terms of reasonableness, this article argues that accrediting requires special care to avoid penalizing conduct that, despite its otherwise questionable character, may not restrain trade at all. See infra note 98.

Although this analytical framework has not been fully articulated in any accrediting case, one court of appeals warned professional organizations to be "aware that a practice intended to benefit the public may have a collateral adverse effect on competition. If it does, then such practice must be the least restrictive means of achieving the desired goal and the public benefit rendered must outweigh the adverse effect on competition." Kreuzer v. American Academy of Periodontology, 735 F.2d. 1479, 1496 (D.C. Cir. 1984). Although this statement suggests an analysis similar to that outlined in this article, it would be a defensible statement of law only if, instead of stressing the "public benefit" of the association's quality-promoting standard (implying that competition may be sacrificed for a socially worthy purpose), the court had spoken of its procompetitive value. Indeed, the court should have acknowledged that competitors do not necessarily restrain trade or violate the law when they combine to tout their own services-that is, to compete-rather than to perform some public service. See supra note 88. The case is a good example of how beginning the analysis with a presumption that the provision of information restrains trade can lead a court into confusion. 
present danger" to competition and consumer welfare if the speech in question escapes all antitrust scrutiny. ${ }^{96}$ Thus, just as deceptive advertising is not protected by the First Amendment, ${ }^{97}$ an accrediting program that grossly manipulates public or consumer ignorance for the competitive and economic advantage of the collaborators is a good candidate for antitrust attention. ${ }^{98}$

But even though the appropriateness of some antitrust oversight of private accrediting is fairly clear, the appropriate nature and scope of that oversight is not. Because private accrediting does not inherently restrain trade, however, it would seem that its analysis under the antitrust laws should resemble the analysis of ancillary restraints-that is, agreements that restrict competition between competitors only to accomplish an overriding procompetitive purpose. ${ }^{99}$ Thus, courts should apply the rule-of-reason principle that collaborators in a joint undertaking must not restrict competition any more than is reasonably necessary to carry out their legitimate objectives. Accordingly, a court should scrutinize an accrediting program to ensure that the parties eschewed explicit anticompetitive agreements. ${ }^{100}$ There is also room here for a court to consider whether the standards adopted were reasonable ones or might have been written or administered in a less anticompetitive way. It is in considering the substantive validity of accrediting standards or their application, however, that trouble is bound to arise. ${ }^{101}$

Although the premise that accrediting serves procompetitive informational purposes begins to give way as soon as one recognizes the possibility of unfair

96. See Schenck v. United States, 249 U.S. 47, 52 (1919) (framing first amendment test as "whether the words used are used in such circumstances and are of such a nature as to create a clear and present danger that they will bring about the substantive evils that Congress has a right to prevent").

97. See, e.g., In re R.M.J., 455 U.S. 191, 199-200 (1982); Friedman v. Rogers, 440 U.S. 1, 10 n.9 (1979).

98. See Havighurst \& King, supra note 5, at 153:

The problem of unfair [accrediting] is comparable in this respect to the problem of deceptive advertising, and indeed may be more serious. Consumers can readily perceive advertising's self-serving character and may consequently greet it with a healthy skepticism. They may be significantly less skeptical toward [accrediting] as a result of its apparently objective and authoritative character, the professional auspices under which credentials are granted, and the typical absence of competing claims.

The antitrust laws, however, do not provide an automatic warrant for policing all unfair or deceptive accrediting. Just as unfair single-firm conduct can be attacked as an "attempt to monopolize" under section 2 of the Sherman Act, 15 U.S.C. $\$ 2$ (1988 \& Supp. IV 1992), only if it creates a dangerous probability of monopoly, Spectrum Sports, Inc. v. McQuillan, 113 S. Ct. 884 (1993), a probable restraint of trade, not just unfair competition, must appear in a section 1 case. The tendency of courts to focus on effects, see supra notes $\mathbf{9 0 - 9 1}$ and accompanying text, should therefore be seen as a search for real effects on competition, not competitors, and as an effort to avoid making the antitrust court a forum for resolving disputes that should be handled under state law governing unfair competition, defamation, and so forth. See Havighurst \& King, supra note 5, at 168-69.

99. See supra note 95.

100. See supra notes $52-68$ and accompanying text.

101. See supra text accompanying notes $20-21,48-49$. The less-restrictive-alternative requirement, as an element of the rule of reason, must be applied reasonably, not used as an excuse to second-guess or regulate the conduct of firms collaborating in good faith for a procompetitive purpose. See generally AREEDA, supra note 1, I 1505, at 383-89. Courts thus have no warrant under the Sherman Act to scrutinize private accrediting too closely. 
or deceptive accrediting, it is doubtful that antitrust courts could rectify the problem by subjecting accrediting standards or actions to judicial review. In many cases, courts would be simply unable to judge with any confidence whether a questioned standard or accrediting action was unlawful under the rule of reason. Most accrediting standards and actions are not based on verifiable fact but depend instead on technical judgment, which may be influenced by or mixed with ideology or self-interest. ${ }^{102}$ Objective evaluation of accreditors' actions. would therefore be difficult for courts. Moreover, judicial review would quickly trespass on first amendment values. For example, even if the court in the Massachusetts School of Law case were to find reason to question the six challenged criteria employed by the ABA in accrediting law schools, it should ultimately find them very hard to second-guess. ${ }^{103}$ It would be similarly difficult for a court to declare that the ACPE's proposal to require six years of training for pharmacists reflects anything other than an honest opinion of the proponents. Because it is impossible in most cases to identify dishonesty or an anticompetitive intent in the statement of an opinion, courts will rarely be able to ensure that accrediting programs operate above the fray or are more procompetitive than anticompetitive in their impact.

Antitrust cases involving private accrediting have yielded no clear set of guidelines regarding the depth of review that will be employed, the kinds of evidence that will be taken on the merits of a standard or decision, or the extent to which (or even the direction in which) evidence of commercial motives will influence the outcome. More often than not, in fact, courts have not had to confront the ultimate question of a standard's substantive validity. In the two leading Supreme Court cases, for example, violations were found not because the standards were judged improper but because certain interests manipulated an association's standard-setting processes for an anticompetitive purpose. ${ }^{104}$ Many lower court rulings have come at a preliminary stage of the litigation,

102. See Havighurst \& King, supra note 5, at $189-92$ (noting that "it is surprising how soon one leaves the field of established scientific truth in standards and enters areas in which judgment, opinion, and conventional wisdom-all easily influenced by self-interest-predominate"; observing "the immense practical difficulty of correcting by regulatory means any but obvious defects in [accrediting] systems"). Accreditors typically impose higher standards than are obviously necessary to protect the public against poor quality. In so doing, they are unlikely to be opposed by government. See supra text accompanying note 51. Yet higher standards often translate into higher entry costs, limited supply, limited competition from low-cost alternatives, and higher incomes for the providers of accredited services. Although second-guessing high standards is difficult, courts might usefully observe that, ultimately, the necessary trade-offs should be made by consumers in the marketplace, not by private accreditors, who are apt to have a conflict of interests in advising or speaking for consumers. See supra note 89.

103. Those criteria relate to faculty salaries; student-faculty ratios, teaching loads, and sabbaticals; use of the Law School Admission Test; library requirements; bar exam preparation for credit; and student employment. Massachusetts Sch. of Law at Andover, Inc. v. ABA, 853 F. Supp. 837, 845 n.4 (E.D. Pa. 1994).

104. Allied.Tube \& Conduit Corp. v. Indian Head, Inc., 486 U.S. 492 (1988); American Soc'y of Mechanical Eng'rs, Inc. v. Hydrolevel Corp. 456 U.S. 556 (1982). 
before final substantive review of an accrediting action was required. ${ }^{105}$ In other cases, courts have avoided close scrutiny of debatable accrediting standards on the ground that, since loss of accreditation was not finally disabling to the plaintiff, the accreditor was entitled to its opinion. ${ }^{106}$ In practice, therefore, courts have not often engaged in de novo substantive review of accrediting actions.

Because antitrust courts are only rarely able to detect bad faith in the formulation or administration of accrediting standards, they usually, in the final analysis, have to defer to the accreditors even on highly debatable points. In addition to giving the public no protection against sophisticated abuses, such judicial review confers on accrediting bodies a status similar to that enjoyed by public regulatory agencies, which are subject to similarly limited review. Indeed, by making private accreditors seem more accountable under law than they are in fact, judicial oversight may significantly increase their prestige and credibility, thus helping to fulfill the prophecy of their power and influence that provided the warrant for judicial review in the first place. Ironically, judicial review of private accrediting under the antitrust laws may have helped to convert already influential accreditors into true private regulators exercising authority with neither political nor effective legal accountability for their policies and practices. $^{107}$ Antitrust courts and enforcement agencies should be alert to this dynamic in formulating their policy toward private accreditors.

Judicial scrutiny of accrediting programs to determine their de facto effects and the reasonableness of both their standards and their administration has another practical drawback: Because de novo substantive review of accrediting standards and determination of their de facto significance are highly factintensive endeavors, every antitrust challenge to an accrediting action is likely to result in protracted, burdensome litigation before a judicial resolution of the challenge can be reached. The unavoidable risk and significant costs of

105. E.g., Kreuzer v. American Academy of Periodontologists, 735 F.2d 1479 (D.C. Cir. 1984) (reversing denial of summary judgment); Daniel v. American Bd. of Emergency Medicine, $802 \mathrm{~F}$. Supp. 912 (W.D.N.Y. 1992) (upholding complaint). See generally Havighurst \& King, supra note 5, at 182 (as of 1983 , "no reported antitrust case has finally invalidated a substantive membership, certification, or similar standard, although several challenges have survived motions to dismiss").

106. See supra note 91; see also Marjorie Webster Jr. College, Inc. v. Middle States Ass'n of Colleges and Secondary Sch., Inc., 432 F.2d 650 (D.C. Cir.) (nonantitrust case allowing accreditor to refuse to accredit proprietary schools because consequences were limited, question was one of "educational philosophy," and the latter schools were free to organize their own accrediting program), cert. denied, 400 U.S. 965 (1970).

107. See Havighurst \& King, supra note 5, at 193-94 (discussing "the danger of perpetuating credentialing monopolies"): "At some point, apparently reasonable judgments would have to be accepted and the credentialing system given a clean bill of health. The resulting judicial imprimatur would confirm the myth of objectivity in credentialing and strengthen the authority of the dominant scheme." See also Havighurst, supra note 6, at 363 (emphasis in original): "Judicial review might simply confirm the defendant organization's status as a quasi-public body, thereby enhancing the credibility and influence of its pronouncements. Thus, if a professional body were willing to incur the cost of defending and even possibly losing an occasional lawsuit, it might achieve the very stature and authority it most covets." 
litigation alone, therefore, might chill some procompetitive accrediting. ${ }^{108} \mathrm{~A}$ specific risk is that an accreditor might settle on standards that are highly inclusive in order to reduce the risk of litigation by those denied recognition. Although such inclusiveness would benefit marginal competitors, it would also make the accrediting program less valuable to consumers as a means of identifying qualitative differences among products or suppliers. A key procompetitive benefit of private accrediting might thus be lost.

Both theory and practical considerations point to the explicit adoption by antitrust courts of a limited form of judicial review of accrediting standards and practices under the antitrust laws. In the first place, courts should acknowledge the freedom of private, self-interested groups to express their opinions about the quality or acceptability of goods or services being offered, or about competitors present, in the marketplace. ${ }^{109}$ They should also acknowledge the inappropriateness of judicial regulation of the opinions thus exposed. The limited scope of judicial review in constitutional challenges to governmental actions not affecting fundamental rights signifies the constitutional legitimacy of the actors whose actions are being scrutinized; private entities exercising their freedom of commercial speech should enjoy comparable deference from the legal system. In addition to confessing their institutional incompetence to regulate private speech, courts should acknowledge their inability as a practical matter to ensure the integrity or accuracy of any competitor-sponsored accrediting program. An express warning that a private group is free to speak only because it is free to speak and not because its opinions are necessarily trustworthy would not be out of order. An important object of antitrust doctrine in this field should be to facilitate the granting of summary judgment in cases in which the proffered evidence reveals only a collaborative program to establish and verify compliance with standards, not a naked conspiracy to impose standards in a regulatory way.

While acknowledging the inherent potential for abuse in private accrediting, antitrust courts should expressly undertake to apply only a rational basis test to the standards promulgated by competitor groups. ${ }^{110}$ In providing such limited

108. For example, the Kreuzer and Daniel cases, supra notes 88,105 , demonstrate the vulnerability of accrediting bodies to substantial litigation costs and potential liability for the merely publishing rosters of those who meet its standards.

109. See United States Dental Inst. v. American Ass'n of Orthodontists, 396 F. Supp. 565, 580-81 (N.D. Ill. 1975) (finding a true boycott, court observed that "[d]efendants did not limit themselves ... to exercising their First Amendment rights to criticize" the plaintiff).

110. See generally Havighurst \& King, supra note 5, at 164-69, 173-84. See also Havighurst, supra note 6, at 364-65:

[A]pplication of the rule of reason to detect adverse effects on competition under this theory need not involve more than a "quick look" by which the court can satisfy itself that the defendants lacked market power or that the information or opinion tendered had a rational basis. No more extensive scrutiny should be undertaken, because there is no less restrictive way to accomplish the procompetitive informational purpose and [because] the activity is more procompetitive than anticompetitive. Not being facially inconsistent with the maintenance of competition as a process, collective speech should not have to be justified affirmatively on the ground either that it is disinterested or that its informational content actually advances consumer welfare. 
scrutiny, a court would examine an accrediting standard or action only to ensure that it was facially procompetitive. The inquiry would not focus on whether the standard benefitted consumers in fact, was the least restrictive or most reasonable standard that could have been written, or had a demonstrable objective basis. Instead, the court would defer to the accreditors' judgment once it found a rational connection to a purpose that could reasonably be deemed to be procompetitive-in the sense of helping consumers or other users to decide for themselves. It would be of no concern that the collaborators were not serving the public interest but were instead attempting to persuade people (including government) to prefer their goods or services over those of their competitors-that is, were competing for the favor of independent decisionmakers.

In using a rational basis test, an antitrust court would not abdicate all responsibility for preventing abuses by powerful private accreditors. Indeed, such a test would permit effective challenges to many questionable practices, such as conditioning accreditation on irrelevant criteria, ${ }^{111}$ using design criteria when less restrictive performance criteria were clearly feasible, or foot-dragging in the recognition of improved products. ${ }^{112}$ The key issue would be whether there are overt signs that the collaborators were not, in fact, primarily interested in informing interested parties of the relative merits of certain goods and services. A court could intervene if it clearly appeared that the parties were instead trying to deceive information-starved consumers, to manipulate an unresponsive government program, ${ }^{113}$ or to exploit some other market imperfection to advance their own interests. ${ }^{114}$

Limited antitrust review of private accrediting would have several important virtues. One crucial benefit of a new judicial approach to these cases would flow from explicit judicial recognition that an accrediting body's standards are only its opinion, which it is free to express. Either explicitly or by implication,

111. See, e.g., Bogus v. American Speech \& Hearing Ass'n, 582 F.2d 277 (3d Cir. 1978) (making payment of association dues a prerequisite for certification held possible violation); United States $v$. American Soc'y of Mechanical Eng'rs, 1972 Trade Cas. (CCH) q 74,029 (S.D.N.Y. 1972) (consent decree requiring defendant to drop policy of not certifying foreign-made products).

112. For a discussion of how the unfortunate result in Structural Laminates, Inc. v. Douglas Fir Plywood Ass'n, 261 F. Supp. 154 (D. Or. 1966) (denying antitrust relief to inventor of new kind of plywood, which failed when association withheld seal of approval for product for six years under design criteria), affd, 399 F.2d 155 (9th Cir. 1968), cert. denied, 393 U. S. 1024 (1969), could have been avoided even under limited antitrust scrutiny, see Havighurst \& King, supra note 5, at 181 . See also id. at 19899 n.224 for examples of how the rational basis test would apply in a wide variety of standard-setting situations identified in STANDARDS AND CERTIFICATION, supra note 19.

113. On the applicability of the Noerr-Pennington defense, see supra notes 46,47 and accompanying text.

114. In the case of the ACPE, a plaintiff might be able to allege successfully a conspiracy by the ACPE and its constituent pharmacist interests to abuse their powerful position for the purpose of raising entry barriers in pharmacy, eliminating one of two competing manpower categories, and raising the cost of and eliminating diversity in pharmacy education. The new training requirement might be open to challenge even under the rational basis test because the elimination of one of two credentials signifies an intent to eliminate and obscure, rather than to publicize, relevant differences between practitioners. 
courts should convey that the opinions of such entities may be self-interested and are not necessarily to be relied upon by consumers, their agents, or government. The resulting reduction in the credibility of dominant accreditors, which could no longer claim that their standards and practices were subject to comprehensive judicial review, might open the door for other accreditors. Judicial skepticism toward private accreditors might also induce independent decisionmakers to seek other, confirming information and, in general, to think for themselves rather than merely accepting the judgments of the dominant accreditor. Accreditors might feel freer to express debatable opinions, providing consumers with better grounds for differentiating between products or providers of services. In several ways, a more laissez-faire environment would enhance the likelihood that competing accreditors would emerge, offering consumers a wider range of information and advice and contributing to a healthier marketplace - of ideas as well as goods and services. ${ }^{115}$

A final benefit of reviewing private accreditors under a rational-basis standard would be to put accreditors in a better position to obtain summary judgment in cases where they had limited themselves to producing information bearing on issues of concern to consumers. To be sure, some competitors disadvantaged by adverse accrediting decisions would find the path to judicial relief blocked. But their market opportunities might be broadened over all. Present law, after all, creates more the appearance of accreditor accountability than the real thing.

The judicial self-restraint counselled here, in addition to being clearly de jure rather than merely de facto, would differ from current judicial practice in one other essential respect. Instead of reflecting a presumption (or finding) that private accrediting advances worthy social purposes as a surrogate for government regulation, the recommended policy would rest on premises truer to the antitrust tradition. First, it would recognize that private accrediting programs are entirely compatible with competition-and thus with antitrust law-as long as they do no more than generate information on which independent decisionmakers can act and do not involve actual boycotts or naked anticompetitive agreements of other kinds. Second, it would acknowledge that, even though competitor-sponsored accrediting is unlikely to be wholly disinterested, industry groups are generally free to express their opinions concerning goods or services being offered in the marketplace, however debatable or influential those opinions may be. Indeed, antitrust policy should

115. In Marjorie Webster Jr. College, Inc. v. Middle States Ass'n of Colleges and Secondary Sch., Inc., 432 F.2d 650, 655-58 (D.C. Cir.), cert. denied, 400 U.S. 965 (1970), the court applied common-law principles and the equivalent of limited judicial scrutiny in permitting an educational accreditor to maintain a standard not easily equated with educational quality. Recognizing the philosophical character of the dispute, however, the court suggested that the disadvantaged school could collaborate with similar institutions in an accrediting scheme of their own. See also Sherman College of Straight Chiropractic v. United States Comm'r of Educ., 493 F. Supp. 976, 980 (D.D.C. 1980): "Plaintiffs themselves emphasize their distinct view of the chiropractic profession. The proper channel for their efforts is to establish their own chiropractic accrediting agency and secure federal recognition for it." 
make clear that-in a competitive economy, just as in a robust political system-self-interested collective speech is generally not objectionable in the eyes of the law. Borrowing from the first amendment tradition, this article maintains that the best answer to debatable commercial speech is more speech-a dynamic marketplace of ideas. A policy of judicial self-restraint toward private accrediting would thus find sanction both in first amendment principles and in antitrust policy itself, which contemplates that competitors will jockey for commercial advantage with only limited refereeing by courts.

\section{IV}

\section{ANALYZING EFFECTS IN THE MARKETS IN WHICH ACCREDITORS THEMSELVES COMPETE}

It would not be easy, however, for courts or antitrust enforcers to adopt an explicit policy of self-restraint toward private accreditors, expressly foreswearing close scrutiny of accrediting actions or standards. Indeed, antitrust authorities, once they are alert to the subtle abuses possible in private accrediting, are more likely to perceive their duty to lie in the direction of stricter scrutiny. Thus, only if there is another way to prevent powerful private accreditors from misusing their influence can antitrust agencies and courts reasonably be expected to acknowledge openly their limitations as regulators of commercial speech. The discussion below demonstrates how antitrust law could protect the public against unfair and deceptive accrediting without policing private accrediting as such-and do so more effectively than is possible under current, more regulatory approaches.

The impulse of antitrust authorities to police accrediting abuses under the antitrust laws originates, ultimately, in their lack of confidence in the market's ability to produce alternatives to unreliable information that may emanate from powerful accreditors. In other words, antitrust observers of private accrediting seem to share an intuitive concern about ineffective competition and market power in the market for information itself. Such a concern is well justified. Yet antitrust enforcement efforts have always focused only on the state of competition and competitors in markets in which accredited services or products are bought or sold. Attention has never been directed explicitly to the problem of fostering competition in markets in which accreditors themselves compete, producing information and opinion for public consumption. If antitrust enforcers and courts could identify remediable restraints of trade affecting the quantity, variety, and quality of the information being generated in such markets, they might no longer feel bound to follow cold trails, searching for harms to competition only in markets in which the effects of information are felt.

Focusing on the competitive conditions under which information and opinion are produced would yield an antitrust agenda strikingly different from the one implicit in current antitrust doctrine applicable to private accrediting. Instead of relying on judicial review of accrediting standards or of actions taken in 
verifying compliance with them, the antitrust agenda to be recommended here would use conventional antitrust doctrine to contest the very existence of certain accrediting bodies that are powerful enough to dominate their respective fields and to dictate standards for an entire industry. Thus, it would concentrate on protecting competition in accrediting itself and, more generally, on preventing special interests from monopolizing the production of information and opinion concerning the design, content, and quality of an industry's products or services. In general, antitrust law is better suited to promoting competitive market structures (under which market forces effectively discipline individual firms) than to regulating the day-to-day business conduct of powerful enterprises and joint ventures. ${ }^{116}$ This suggests that an antitrust strategy aimed at curbing monopoly and preserving independent voices in the market for information and opinion might be more successful in protecting consumer welfare than judicial oversight of accrediting programs, standards, or procedures could ever be.

Section 2 of the Sherman Act might seem to be the obvious instrument with which to attack accrediting monopolies. That section, however, prohibits only monopolization, not monopoly itself, and thus focuses principally on the conduct by which a dominant market position was gained. ${ }^{117}$ There are probably few instances in which a dominant accreditor could be accused of exclusionary practices of the kind that section 2 has been held to target. ${ }^{118}$ A more promising line of antitrust attack would therefore be to enforce section 1 of the Sherman Act against joint ventures in which two or more independent trade or professional associations combine forces to undertake accrediting in a particular field. ${ }^{119}$ Joint ventures in accrediting-of which there are many-permit

116. In Copperweld Corp. v. Independence Tube Corp., 467 U.S. 752 (1984), the Supreme Court discerned in the Sherman Act a statutory scheme designed to limit the occasions for scrutinizing the unilateral conduct of lawful entities:

The conduct of a single firm . . . is unlawful only when it threatens actual monopolization. It is not enough that a single firm appears to "restrain trade" unreasonably, for even a vigorous competitor may leave that impression. ...

... In any conspiracy, two or more entities that previously pursued their own interests separately are combining to act as one for their common benefit.... O Of course, such mergings of resources may well lead to efficiencies that benefit consumers, but their anticompetitive potential is sufficient to warrant scrutiny even in the absence of incipient monopoly.

Id. at 767, 768-69. For specific examples of how antitrust courts have been led into regulating conduct when structural relief was more appropriate, see infra notes 130-32 and accompanying text.

117. The general test for the legality of market power is whether it was gained improperly, such as by employing some exclusionary practice. United States v. Grinnell Corp., 384 U.S. 563, 570-71 (1966).

118. An accreditor's success in obtaining recognition by a government agency would presumably be unassailable because of the Noerr-Pennington doctrine. See supra notes $46-47$ and accompanying text. If an accrediting program was subsidized by its sponsors and therefore charged below-cost prices for accrediting services, it might be charged with predatory pricing aimed at preventing competing accreditors from entering the field. Such a charge would pose substantial analytical problems, however, because information, as a public good, will always be underproduced without subsidies of some kind.

119. Although section 1 applies to any competitor-sponsored accrediting program (as discussed above), it is much more likely to prevent abuses when brought to bear on joint ventures by independent professional and trade associations, which can be regarded as competitors in the market for information, a discrete commodity. Whereas an accrediting body formed by competitors in the field to be accredited is procompetitive on its face, a joint venture by competing producers of information directly eliminates 
organizations having complementary but sometimes conflicting interests and viewpoints to speak with one voice on many questions that should come before consumers for resolution in the marketplace. Their collaboration moves much of the debate on such questions behind closed doors and reduces the number of sources to which consumers can look for authoritative information and advice. It is submitted that the resulting loss of "competition" in the production and dissemination of information and opinion ought to be a subject for possible antitrust enforcement.

Concerted action restricting an industry's output is normally a matter of serious antitrust concern. There is no obvious reason why it should be of any less concern when the product whose production is curbed is information of a commercially significant kind. ${ }^{120}$ Thus, section 1 provides the logical instrument for challenging collaboration between industry groups seeking to control the supply of information on which consumers and others rely in making difficult market choices. To be sure, the Sherman Act has never been applied to joint ventures of this kind. But that is merely an oversight caused by the failure to appreciate that consumer information is itself a product that should be produced to the greatest extent possible under competitive conditions. That oversight has allowed insiders in many industries to control one of the critical levers of power in any political-economic system-the information that people need to exercise whatever sovereignty they possess. This oversight should now be rectified.

Many private accrediting bodies are, in fact, conventional joint ventures cosponsored by independent organizations and thus potential candidates for scrutiny under section 1 . The sole accreditor of pharmacy schools (the ACPE), for example, is a joint venture of the American Pharmaceutical Association (comprised of practicing pharmacists), the American Association of Colleges of Pharmacy, and the National Association of Boards of Pharmacy; these three

competition inter se, triggering a more rigorous kind of antitrust scrutiny. Note also that section 2 is also available to challenge mergers or joint ventures by which a true monopoly is achieved. E.g., Grinnell Corp., 384 U.S. 563.

120. It only confuses the issue to observe the effects that limitations on the output of information have on competition in other markets - that is, in markets where the accredited firms (or certified products) compete. Whatever those effects may be, the restriction on competition in the production of valuable consumer information should be the principal focus of antitrust attention. Of course, if consumers and others appear to rely on other sources of information and to discount the opinions of the joint venture in making their choices in the other market, that evidence would suggest that the market for information is competitive enough to permit the joint venture to continue.

There is one important respect, however, in which it does matter that the consequences of reduced competition in a particular market for information are felt in a particular commercial field. The Sherman Act, after all, governs informational activities only when they affect commerce, and serious first amendment barriers would be encountered if it were invoked against anything other than commercial speech. See supra notes 82-85. Thus, the Sherman Act has been construed not to apply to informational or other practices aimed at influencing political action or at achieving a noncommercial objective. See supra text accompanying notes $46-47$ (discussing the Noerr-Pennington doctrine). For cases holding boycotts to achieve political or social objectives beyond the reach of the Sherman Act, see NAACP v. Claiborne Hardware Co., 458 U.S. 886 (1982); Missouri v. National Org. for Women, 620 F.2d 1301 (8th Cir.), cert. denied, 449 U.S. 842 (1980). 
organizations have strong, though not identical, interests in how the field of pharmacy evolves. ${ }^{121}$ Similarly, the JCAHO is a joint venture of the AMA, the American Hospital Association, and the two most prominent associations of physicians and surgeons. ${ }^{122}$ The list of potential antitrust targets goes on, including the Liaison Committee on Medical Education (the AMA and the Association of American Medical Colleges), which accredits medical schools; ${ }^{123}$ the American Board of Medical Specialties (the "ABMS") (twenty-four medical specialty boards and six national organizations), which accredits certifiers of medical specialists; ${ }^{124}$ the Accreditation Council for Graduate Medical Education (five physician, hospital, and educational organizations); the Accreditation Council for Continuing Medical Education (the "ACCME") (seven members); ${ }^{125}$ and innumerable joint boards through which the AMA participates with dominant organizations in various allied health fields in credentialing health care personnel and accrediting their training programs. ${ }^{126}$ Although the ABA's accrediting program for law schools is not organized in conjunction with any other organization, the most telling-and possibly the only valid-allegation against it in the pending lawsuit by the Massachusetts School of Law is that it conspired with the Association of American Law Schools in setting and applying its standards. ${ }^{127}$

Obviously, any proposed legal theory that threatens to put so many wellentrenched institutions out of business will be received with skepticism by some observers and with alarm by many. It is submitted, however, that antitrust scrutiny of joint ventures in accrediting "follows inexorably from a recognition

121. Treating the National Association of Boards of Pharmacy as a coconspirator might seem anomalous because its members are public agencies. Nevertheless, it essentially represents, and is represented on the ACPE board by, practicing pharmacists. Although one of ten votes on the ACPE board belongs to the American Council on Education, a body having virtually no stake in pharmacy or pharmacy education, its token involvement, like the presence of a few "public members" on the boards of other accreditors, does not alter the ACPE's character as a creature of narrow industry interests.

122. See Havighurst \& King, supra note 5, at 323-34. Although the JCAHO plans soon to alter its governing body so that physicians no longer constitute a majority, that alone would not ensure compliance with the Sherman Act.

123. Id. at 321-23.

124. See generally ABMS, ANNUAL REPORT \& REFERENCE BOOK-1994, at $46-59$ (including detailed description of structure and interrelationships of various medical and accrediting organizations). See also Havighurst \& King, supra note 5, at 311-14 (discussing the ABMS, which may be an acceptable accreditor of specialty boards, primarily as an unlawful market-division arrangement by which each member board agrees to respect the territory of-i.e., not to compete with-other boards). The American Dental Association performs functions comparable to those of the ABMS in accrediting specialty organizations in the field of dentistry. See, e.g., Kreuzer v. American Academy of Periodontologists, 735 F.2d 1479, 1483 (D.C. Cir. 1984) ("[T]he ADA also serves as a mediator and arbiter of the scope of dental specialties.").

125. See Havighurst \& King, supra note 5, at 316-19 (describing not only the ACCME as a joint venture but also some actual mergers by which it was created).

126. See generally id. (pt. 1) at 148-49; see also id. (pt. 2) at 320-21 (describing a 1976 schism in the field of physical therapy that illustrates both the harm that a joint venture can do and the potential for competition in a given field).

127. Massachusetts Sch. of Law at Andover, Inc. v. ABA, 855 F. Supp. 108 (E.D. Pa. 1994) (denying motion to dismiss AALS as a defendant). 
that information and opinion helpful in making market decisions are valuable commodities whose output, always at suboptimal levels in any event, is subject to restraint by self-interested industry groups."128 Joint venture analysis under the antitrust laws, like merger analysis, focuses on whether the procompetitive virtues of a combination of competitors are outweighed by its anticompetitive effects. A 1983 article coauthored by one of the instant authors developed at length, with examples, the legal theory under which an accrediting program combining the most likely potential competitors in the production of information and opinion concerning a particular area of commerce could be charged with unnecessarily and illegally reducing competition in an important market. ${ }^{129}$ To be sure, such joint ventures could claim that they were organized for the procompetitive purpose of producing a unique product: informed opinion bearing on important issues affecting consumer choices and consumer welfare. But a full rule-of-reason analysis, like the analysis of a merger yielding a firm of monopolistic proportions, should condemn many such ventures. By denying consumers and the public the benefit of competing opinions and advice on critical issues, they substantially reduce the efficacy of the free market, of the "marketplace of ideas," and even of the political process itself (in view of the governmental deference that many accrediting joint ventures enjoy) as forums for resolving issues of great importance to consumers.

There are several reasons why conventional antitrust analysis of private accrediting has focused only on effects in markets in which accredited entities, not the accreditors themselves, compete. The most fundamental problem is the tendency of antitrust courts, in this area as in others, to adopt the point of view of alleged victims rather than to concentrate on the maintenance of competitive conditions overall. ${ }^{130}$ Private plaintiffs naturally regard any unfair denial of

128. Havighurst \& King, supra note 5, at 325.

129. Id. at 295-334. Although no court or enforcement agency has ever embraced that obviously controversial theory, it has never been raised in litigation or refuted on the merits in scholarly debate. For an attempted defense not addressed primarily to the legal merits, see James W. Rankin \& Bruce A. Hubbard, Private Credentialing of Health Care Personnel: A Pragmatic Response to Academic Theory, 10 AM. J.L. \& MED. 189 (1984); see also Clark C. Havighurst \& Nancy M. King, Correspondence, 10 AM. J.L. \& MED. 459 (1984). One can understand, however, why public enforcement agencies might be unwilling to pursue an innovative legal theory with such seemingly explosive implications. Nevertheless, remedial measures are available that obviate the more radical restructurings seemingly contemplated by Havighurst \& King. See infra text accompanying notes $140-47$.

130. This is not the place to develop in detail the many ways in which antitrust analysis is regularly distorted by the exigencies of private litigation. It is not uncommon, however, for a private antitrust plaintiff, rather than seeking extirpation of the basic violation that creates its competitive problems, to opt for a legal theory under which the court would impose a regulatory decree aimed at softening some effect of market power. See, e.g., Broadcast Music, Inc. v. CBS, 441 U.S. 1 (1979) (plaintiff network sought unsuccessfully to compel two dominant performing rights societies to license music on per-use basis, which would be convenient for it but not for most of its competitors; plaintiff failed to challenge legality of societies themselves, apparently preferring to seek competitive advantage for itself rather than restoration of competitive conditions in licensing of musical works); Virginia Academy of Clinical Psychologists v. Blue Shield, 624 F.2d 476 (4th Cir. 1980) (plaintiff psychologists obtained relief against payment policy of physician-controlled health insurers without demanding termination of arguably unlawful control), cert. denied, 450 U.S. 916 (1981); see also supra note 1. The Virginia Academy case is discussed in connection with the problem of remedy in accrediting cases in Havighurst \& King, supra 
accreditation as a restraint of trade and its effects on themselves as the measure of its unreasonableness. To be sure, it would have taken special insight for a plaintiff's lawyer to perceive the effects complained of, not as signs of a restraint in the affected market, but as artifacts of reduced competition in the market for information. But even having had this insight, learned counsel would still perceive tactical advantages in directing the complaint at the accreditor's conduct rather than at its constitution; after all, a remedy restoring competition in the market for information and accreditation would not necessarily yield the plaintiff the recognition it seeks. Thus, in accreditation cases, the remedy sought is always a change in the dominant accreditor's standards, never the removal of artificial output restrictions in the market for information and opinion. ${ }^{131}$ The final irony is that most accrediting bodies, as defendants, would also prefer to fight the battle for these limited stakes rather than to call the court's attention to the defect in the plaintiff's theory, thus inviting a challenge to the accreditor's right to exist in its present form. ${ }^{132}$

Even though antitrust litigation has heretofore paid no attention to competitive conditions in markets for information affecting consumer choices in another market, this discussion reveals the critical importance of such markets. Note that, even though accrediting is itself a service capable of being monopolized, the market for accrediting services as such is not where the greatest threat to competition arises. The critical concern is, instead, with the somewhat larger market for information and opinion concerning the nature and quality of particular products or service providers. Although it might be argued that the latter market does not constitute "trade or commerce," to which the Sherman Act exclusively applies, that argument should fail. Even though the reason for monopolizing accrediting has practically nothing to do with charging monopoly fees for accrediting services, accreditation is still a service for which

note 5 , at $328-30$.

131. Although it would be asking a lot to expect courts to resist letting themselves be used in such an opportunistic way, they should limit themselves to applying the rational-basis test to competitorsponsored accrediting of all kinds and resist the invitation to scrutinize more closely the standards of any accreditor having a questionable constitution. See Havighurst \& King, supra note 5, at 328-29 (footnote omitted):

An unlawfully constituted credentialing body's unfairness toward particular competitors should not be regarded as a lesser included offense (of the structural violation) at which a conductoriented remedy can be aimed for the benefit of the injured competitor-plaintiff. Instead of leaving the larger question of structural violation to be dealt with in another case-perhaps one brought by a public prosecutor-the court should insist that the plaintiff prove that violation and request a remedy aimed at its extirpation. If there is no violation under the limited scrutiny test, then conduct-oriented relief should not be granted.

... Thus, plaintiffs should be denied both damages and specific relief addressed to their particular competitive difficulties unless they select the line of antitrust attack that is most likely to benefit the community at large. In cases where the finding of a violation results not from limited scrutiny but from a structural defect, courts should decline to provide a remedy that leaves the monolith intact with the plaintiffs inside it.

132. See supra note 107 and accompanying text. The defendants in the cases cited as examples in note 130 supra obviously had good reason to go along with the plaintiff's theory rather than raising the stakes. 
fees are charged, not a charitable activity. ${ }^{133}$ The fact that information valuable to consumers is a public good rather than an ordinary commodity capable of being easily bought and sold should not shelter from antitrust scrutiny a conspiracy to limit its production. Where an accrediting joint venture controls the most authoritative source of information on commercially significant subjects, its amenability to attack under the antitrust laws should not be in doubt.

A crucial issue in evaluating any joint venture under section 1 is the market power it can exercise. Ordinarily, a venture's market share, stated as a percentage of industry sales or output, is a key indicator of its market power. In the case of accrediting, however, market power would be impossible to quantify in terms of market share. Even if an accreditor were the only one in its field, it would obviously not be the only source of information and opinion on the many issues it addresses. ${ }^{134}$. Other information sources would be too numerous to identify, however. Moreover, it would be impossible to measure either the volume of their output or its value as a substitute for the official views of the dominant accreditor. But even though an accreditor's dominance could not be calculated in terms of a percentage of sales or output or quantified in any other way, modern antitrust analysis treats market share not as the actual measure of market power, but only as a convenient quantification helpful in making a qualitative judgment about a market's competitiveness. ${ }^{135}$ It should be possible to estimate an accreditor's market power by evidence of its influence and of the degree to which its technical and value judgments are trusted by major market actors, including government authorities. To be sure, many courts already focus instinctively on these facts. But they have yet to discover that their main relevance lies in appraising the power over information possessed by an accrediting joint venture, not in justifying more stringent judicial review of an otherwise lawful accrediting program.

Another issue in appraising the market power of an accrediting joint venture would be ease of entry. If a dominant accreditor had to be concerned about an alternative accreditor's appearing on the scene, it would have to provide good information and honest advice in order to retain public confidence and deter such entry. In other words, potential competition would prevent it from exercising market power by producing inferior products-that is, by engaging in unreliable accrediting. Conversely, potential competition is reduced when a joint venture encompasses all of the organizations in the field with interests and resources great enough that they might engage in accrediting on their own or

133. Even if no money changed hands in return for accreditation, that would mean only that the joint venturers were rendering valuable services to their members in return for their dues or other contributions.

134. See the quotation from the Consolidated Metal case, supra note 81.

135. See Department of Justice \& Federal Trade Comm'n, Horizontal Merger GUIDELINES $\$ 2.0$ (Apr. 2, 1992) (noting that "market share and concentration data are only the starting point for analyzing the competitive impact of a merger"). 
find other effective ways to voice their concerns. In one widely noted case, the court stated that the remedy of a plaintiff complaining of an inappropriate accrediting standard, was to join with other similarly situated competitors to establish their own accrediting body. ${ }^{136}$ Although this was a valid response in the circumstances, entry is apt to be difficult enough that its prospect will only rarely offset the market power of a dominant joint venture enough to allay antitrust concerns.

Because accrediting features significant economies of scale and has some characteristics associated with natural monopoly, it would not be surprising to find only a single accreditor in many discrete fields. Moreover, anyone who views private accrediting as professional or industry self-regulation might think it is redundant for a given market to have more than one accreditor. Nevertheless, there is room for competition in accrediting precisely because alternative accreditors do not necessarily provide duplicative services-that is, identical answers to identical questions. Only rarely, after all, is there a single, discoverable right answer to every question that an accreditor purports to answer or only one right way to evaluate competing products or competing providers of services. Competition policy should value the fact that different accreditors would have different opinions on debatable issues, would make different trade-offs, would adopt different standards, and would employ different methods of evaluation. Although some observers might find multiple accreditors confusing and yearn for a definitive opinion, pleas for complete standardization of a field should be directed, not to antitrust authorities, but to government, which can adopt regulatory standards if it chooses. ${ }^{137}$

Because of scale economies, entry barriers, and other factors, a court might hesitate to condemn an accrediting joint venture out of fear that breaking up the venture might leave a vacuum that no one would fill. A possible remedy, however, would be to allow one member of the joint venture to assume control of the accrediting program. Although that remedy would leave an apparent accrediting monopoly in the field, the public might be better served precisely because that accreditor would have lost some of its previous prestige as the only authoritative spokesman in the field, opening the door for competing viewpoints to be heard. ${ }^{138}$ Consumers and others (including government agencies) that

136. See supra note 115.

137. There are several fields (law schools and physical therapy training, for example) where multiple accreditors having different standards satisfactorily coexist. Competing accreditors have recently been recognized by the Health Care Financing Administration in the home health field. See 58 Fed. Reg. 35,007 (1993) (recognizing the JCAHO); 57 Fed. Reg. 22,773 (1992) (recognizing the Community Health Accreditation Program). On the desirability of competition in educational accrediting, see supra note 36.

138. Some might fear that breaking up an accrediting joint venture would undermine the ability of a successor accreditor to support a costly program, and any resulting loss in the quality of accrediting might be urged as a basis for permitting the more broadly based effort. Consumers might be better served, however, by sacrificing some economies of scale that permit more rigorous accrediting in return for greater diversity of ideas about what constitutes quality in the accredited field. In any event, changing the sponsorship of an accrediting program would not, in itself, affect the accreditor's ability 
had previously accepted the judgments of the joint venture would then have to reconsider their reliance. Moreover, the former partners of the surviving sponsor would be in a position to criticize the accreditor's policies and performance as well as to set up a competing accreditor if the need arose. Whatever criticism and debate ensued-even though it would strike many in the industry as unseemly, confusing, and regrettable -would be precisely the kind of competition in the marketplace of ideas that should be cultivated to prevent special interests from controlling their respective fields. ${ }^{139}$

Thus, even though there is no guarantee that actual competition in accrediting would ensue if a dominant accrediting joint venture were disbanded, consumers might still benefit. Competition-in the form of open criticism and debate-would put new pressure on the surviving accreditor to maintain its credibility, would dilute influence that it might otherwise misuse, and would keep open channels by which new ideas, products, and practices could emerge in the affected industry. Preventing competing interest groups from combining to resolve their differences behind closed doors would also have a significant political consequence: The increased potential for public debate would itself make it harder for government-which dislikes controversy-to fall in behind the dominant accreditor and accept its judgments for regulatory or other purposes. Deprived of the easy option of ratifying whatever the best-organized interests work out among themselves, government would have to take responsibility for choosing among competing arguments, interpretations, or philosophies. In this interesting way, antitrust enforcement could force government to accept responsibility for public choices rather than delegating choices to private groups. In general, antitrust enforcement to protect competition in the production of commercial speech and market-relevant information would improve the ability of the marketplace to accommodate differences of opinion and philosophy and to inform consumers, their agents, and other market actors about the full range of options available.

Reluctance to break up respected joint ventures might still cause some courts and politically sensitive antitrust enforcers to resist the force of the arguments presented here. There is, however, another, less troublesome remedy that might

to realize scale economies or even to operate as a natural monopoly. Moreover, if the perceived decline in the quality of accrediting arose from a decline in the accreditor's prestige and credibility (and thus in its ability to charge high accreditation fees), it would be ascribed more accurately to a strengthening of competition in the information marketplace than to a loss of efficiency.

139. Under the legal theories advanced in this article, an accrediting program operated by a single trade or professional organization would escape all but limited antitrust scrutiny. It would have to be careful, however, about consulting with other independent organizations to satisfy their publicly expressed concerns. It is here perhaps-because cooperation to head off controversy seems so natural-that the proposed theory may be most counterintuitive. Nevertheless, the Massachusetts School of Law case, see supra notes 7, 20, 103, 127 and accompanying text, may dramatize the harm in letting a prestigious accreditor work closely with other interests in designing standards that foreclose options for consumers. In any event, maintaining a legal regime that can penalize collective efforts to suppress controversy and foreclose public debate on commercially important issues would provide an inducement for accreditors to adopt the alternative, discussed infra, of widening their membership to include all affected interests, not just special ones. 
be imposed once an accrediting joint venture was found to be unlawful. Instead of dissolving the joint venture, a court or agency might require only that its membership be expanded to incorporate a fuller range of affected interests. In this way, antitrust law could both reduce the power of certain private groups to resolve crucial questions and avoid significantly disrupting existing accrediting programs. Moreover, once antitrust enforcers established their legal authority to demand this relief, many accrediting joint ventures could be expected to move voluntarily to broaden their membership. Accreditors comprising a full range of affected interests would not only permit wider participation in the development and application of standards but would tend to take only actions that enjoyed a near-consensus of support. Standards or actions that seriously offended any participating group could easily become the subject of active, healthy debate outside the accrediting body itself-including widespread noncompliance with the accreditor's requirements. A joint venture comprising all the interested parties would not constitute (as narrower accrediting joint ventures seem to do) an agreement by the participants not to compete by taking controversial issues to the marketplace.

The legal basis for broadening the membership of an accrediting joint venture is fairly clear. The most relevant body of antitrust law is the so-called essential-facilities doctrine, under which certain procompetitive joint ventures can be required to admit competitors as members (on reasonable terms) if their exclusion would fail to satisfy the rule of reason. ${ }^{140}$ In general, the lessrestrictive-alternative requirement of the rule of reason requires any procompetitive collaboration to assume a form that poses no unreasonable danger to competition. It should not be difficult to argue that any powerful accrediting joint venture that is justified on its face by scale economies and by its value as an information source is required to give adequate representation to all of the interests that might be significantly affected by its actions.

In fact, many of the most respected and successful standard-setting organizations and accreditors already satisfy this requirement. Thus, the certifying body with which the Supreme Court was concerned in the Allied Tube case was a broad-based, safety-oriented association "representing industry, labor, academia, insurers, organized medicine, firefighters, and government." Similarly, the defendant in the Hydrolevel case, the American Society of

140. See supra note 95 , discussing the essential-facilities doctrine as a possible instrument for requiring an accreditor to alter its standards or to accredit a competitor against its will. In the instant context, the issue is not the exclusion or unfair treatment of competitors themselves but the anticompetitive potential of a powerful yet generally procompetitive joint venture that incorporates certain interests while excluding others. The essential-facilities doctrine is relevant because it provides precedent for aiming antitrust remedies at the makeup of procompetitive joint ventures. To be sure, the law should not discourage innovative or risky initiatives by depriving joint venturers of the fruits thereof. But requiring a powerful accrediting program to broaden its membership would not appreciably undermine incentives to embark on undertakings that are truly procompetitive.

141. Allied Tube \& Conduit Corp. v. Indian Head, Inc., 486 U.S. 492, 495 (1988) (characterizing the National Fire Protection Association as a "quasi-legislative" private body whose "standards are widely adopted into law by state and local governments"). 
Mechanical Engineers, comprises experts concerned with technical issues in a wide range of industries rather than being controlled by narrow interests in a single field. ${ }^{142}$ Because such broad-based joint ventures are not controlled by special interests seeking systematic advantage over uninformed consumers or over certain competitors, their makeup presents no antitrust problem. ${ }^{143}$ To the contrary, by their nature they incorporate checks and balances that minimize dangers to competition. ${ }^{144}$

Antitrust law thus arguably requires that any accrediting joint venture that can plausibly claim that economies of scale require the collaboration of multiple actors must allow other affected interests to participate on reasonable terms. Thus, the ACPE might be required by antitrust principles to include as full participants representatives of such other interests as pharmaceutical manufacturers, chain drug stores, organized health plans, and consumer groups. Likewise, the JCAHO, long dominated by physicians, could seemingly be required to rewrite its charter to allow representatives of large purchasers, various financing entities, allied health personnel and other hospital employees, and consumers (not just public members selected by the joint venturers themselves) to participate in its governance and in its standard-setting committees. Other accrediting joint ventures could also be given a choice between widening their membership and terminating the joint venture altogether. ${ }^{145}$ In the field of educational accrediting, antitrust law could force a restructuring of many powerful joint ventures of which Congress and the Department of Education have been altogether too tolerant. ${ }^{146}$

142. American Soc'y of Mechanical Eng'rs v. Hydrolevel Corp., 456 U.S. 556, 559 (1982). In this case, as in Allied Tube, the antitrust problem arose when special interests manipulated the internal processes of the standard-setting body to disadvantage a competing product. See also Clamp-All Corp. v. Cast Iron Soil Pipe Inst., 851 F.2d 478 (1st Cir. 1988) (insufficient evidence of manipulation of standard-setting program of American Society of Sanitary Engineers).

143. In In re Appraiser Found. Antitrust Litig., 1994 WL 637705, at *10 (D. Minn. 1994), the court suggested, probably erroneously, that a broad-based accreditor might not feature concerted action of the kind to which the Sherman Act applies.

144. In Hydrolevel, the Supreme Court found ASME vicariously liable for treble damages under the antitrust laws for actions of its agents, who issued in ASME's name an unofficial interpretation of its standards damaging to their competitor. The potential for liability of this kind would obviously create strong incentives for the accrediting body to maintain fair procedures and to be alert to conflicts of interests. But see supra note 14 (discussing availability of money damages in certain cases).

145. See supra note 139 (discussing the legal dangers in choosing the latter course).

146. See supra note 36. In the 1992 amendments to the Higher Education Act, sec. 499, $8496(a)(3)$, Congress required that an accreditor recognized by the DOE be "separate and independent" from any "trade association or membership organization." Higher Education Amendments of 1992, Pub. L. No. $102-325$, sec. 499, § 496(a)(3), 106 Stat. 448, 642 (codified as amended at 20 U.S.C.A. $\$ 1099$ b(a)(3) (West Supp. 1994)). It provided a definition of "separate and independent" ( $\$ 496(\mathrm{~b})$ ), however, that was almost a contradiction in terms since it permitted governance by a self-perpetuating board dominated (by as much as 6 to 1) by members of an interested group. Id. $\$ 496(\mathrm{~b}), 106$ Stat. at 643-44 (codified as amended at 20 U.S.C.A. $\$ 1099$ b(b)). There was also a grandfather clause ( $\$ 496(a)(3)(C)$ ) exempting from the independence requirement any professional body (including virtually all the medical profession's accrediting programs) that was recognized prior to 1991 and could demonstrate that "the existing relationship has not served to compromise the independence of its accreditation process ... .$\quad$ Id. $\$ 496(\mathrm{a})(3)(\mathrm{C}), 106$ Stat. at 642 (codified as amended at 20 U.S.C.A. $81099 \mathrm{~b}(\mathrm{a})(3)(\mathrm{C})$ ). Application of the antitrust principles advocated in the text would cause many of the entities seemingly 
This discussion has shown how conventional principles of antitrust law, while still facilitating procompetitive private accrediting, could keep markets for commercially significant information open and competitive. Indeed, it appears that the Sherman Act's rule of reason, although it would permit private accrediting to be carried on under several possible arrangements, ${ }^{147}$ is a potentially powerful tool with which to frustrate efforts by special interests to empower themselves by capturing control of the information flowing to purchasers of the goods or services they sell. Although the antitrust agenda sketched here is unprecedented, there is no longer any good excuse for not invoking antitrust law to foster glasnost in fields where information has too long been controlled by powerful insiders with a stake in keeping consumers incapable of effectively exercising the sovereignty on which the legitimacy and efficiency of private markets depend.

\section{$\mathrm{V}$ \\ CONCLUSION}

This article argues that antitrust law has been barking up the wrong tree in dealing with private accrediting. Parts II and III demonstrated that antitrust law, as currently applied, does not effectively protect consumers against private accrediting that goes beyond providing helpful information and advice and distorts the options available to consumers in the marketplace. Moreover, that critique of current doctrine discovered no way in which to increase the law's effectiveness in policing abuses in private accrediting. Indeed, it was argued that, because of the limited competence of courts in regulating commercial speech, antitrust law should not purport to police any but egregious instances of unfair or deceptive accrediting - that is, abuses detectable in a rational-basis analysis. Thus, the main advice offered to antitrust courts in Part III was only to be more explicit in limiting the scope of their review of private accrediting. To be sure, this counsel gives no solace to competitors complaining of accrediting abuses. But limiting judicial scrutiny on the basis of explicit skepticism about what courts can actually do to combat self-interest in the

\footnotetext{
blessed by these well-lobbied provisions (at least those that represent joint ventures) to be reconstituted so as to be truly "separate and independent" of special interests.

147. Another possible alternative might be to cut the accreditor loose from control of any kind by making its governing board self-perpetuating. An accreditor of this kind might be deemed either to satisfy the rule of reason or to eliminate the element of concerted action necessary to make the Sherman Act applicable. Nevertheless, if the board were comprised only of insiders likely to represent only a narrow range of interests, antitrust law might still apply. An example of an independent accreditor seemingly organized on impeccable lines is the Community Health Accreditation Program ("CHAP"), originally created by the National League for Nursing: "Representatives of business, insurers and individual consumers sit on CHAP's Board of Governors. For the first time in this nation, purchasers of care have a direct say in what constitutes quality. They also serve on CHAP's Board of Review which makes actual accreditation decisions." COMMUNITY HEALTH ACCREDITATION PROGRAM, CHAP: QUALITY THROUGH ACCREDITATION (undated) (promotional brochure; on file with author).
} 
production of commercial information would subtly alter the dynamics of the marketplace of ideas in ways generally beneficial to consumers.

Having shown the limitations of the traditional antitrust approach to accrediting cases, the article then, in Part IV, called the attention of antitrust watchdogs to another field in which to hunt. It was argued that, instead of trying to establish unlawful effects on competition in markets for accredited services or products, antitrust plaintiffs, both private and public, should look elsewhere for redressable harms. On the premise that information and opinion concerning goods and services offered in the marketplace should be produced under competitive conditions to the extent that competition is feasible, the article argued that private accrediting should be subject to antitrust enforcement targeted at artificial restrictions on the output of such information. In particular, collaboration between independent trade and professional organizations in the production of such information should be scrutinized for effects on the quantity, variety, and quality of information flowing to consumers on the subjects in question.

Under the lens of the Sherman Act, many well-entrenched joint ventures in accrediting on which the public is almost exclusively dependent for authoritative information on a wide variety of important commercial and public policy issues begin to look like what they are-conspiracies to ensure that the public hears only the collective opinion of certain industry insiders and is deprived of the benefits of competition in what is essentially a marketplace of ideas. Fortunately, antitrust law, if it could be brought to bear on these joint ventures, offers a variety of possible remedies that, without destroying existing accrediting programs, would ensure that the nation's accreditors are effectively accountable, one way or another, to consumers and their agents. It is submitted that antitrust law should now be recognized as having a crucial role to play in ensuring that competitive conditions prevail in markets in which commercially significant information is produced and in which issues of great concern to consumers are debated and resolved. 